\title{
Ethnicity and mental health: Conceptualization, definition and operationalization of ethnicity from a Canadian context
}

DE Clarke, PhD (1-4); A Colantonio, PhD (3-6); AE Rhodes, PhD (2,3,7-9); M Escobar, PhD (3)

\begin{abstract}
The current study provides a critical review of Canadian studies on ethnicity and mental health with respect to the definition, conceptualization and operationalization of ethnicity. It provides a discussion on the methodological issues related to these factors and their implications to guide future research and enable comparability of results across studies. Sociological Abstracts, PsycINFO, MEDLINE and CINAHL were used to identify relevant Canadian articles published between January 1980 and December 2004. The review highlights a number of key issues for future researchers to consider such as the need for: 1) clear rationales as to why ethnicity is important to their outcome of interest; 2) clarity on the definition of ethnicity, which affects its conceptualization and operationalization; 3) a theoretically driven conceptualization of ethnicity, which should be related to the research question of interest; and 4) clear rationales for the decisions made regarding the data source used, the operationalization of ethnicity, and the ethnic categories included in their studies.
\end{abstract}

Key words: ethnicity, ethnic origin, culture, race, mental health

\section{Introduction}

Canada's immigrant population originates from all over the globe with increasing numbers from Africa, Asia, the Caribbean, and the Middle East (i.e. visible minorities). ${ }^{1}$ Its culturally diverse Aboriginal population adds to the ethnic mix. ${ }^{2}$ Canada prides itself on being a multicultural society by acknowledging the right of every person to identify with his/her cultural background while partaking in the Canadian way of life. $^{3-6}$ This was advocated in its 1971 legislated policy on multiculturalism, which emphasized fair treatment of everyone, regardless of race, colour or ethnicity; particularly in terms of educational and occupational opportunities. ${ }^{3-6}$ Evidence of systemic inequalities, including access to educational and employment opportunities, housing, health and mental health care, are still evident across ethnic groups, ${ }^{7,8}$ which can impact the mental health of the population. ${ }^{2,9}$ For instance, Aboriginal peoples continue to have poorer mental health compared to the general population and, along with visible minorities, have ongoing difficulties accessing culturally sensitive mental health care. ${ }^{9}$ Better understanding of the relationship between ethnicity and mental health is compelling and highly relevant for policymakers and mental health practitioners in the Canadian context.

Canadian literature on ethnicity and mental health is quite limited despite its relevance. Much of the existing studies in this area were conducted in the United States (US) ${ }^{10-15}$ and the United Kingdom (UK) ${ }^{16-19}$ which has uncertain applicability to Canada. The political, social and economic ramifications associated with ethnicity or ethnic identity, likely differ from country to country. Differences in the countries' ethnic compositions, histories of immigration policies and racism/ slavery and ethnic or racial categorizations hinder cross-country comparisons. The history of slavery and segregation has a great deal of meaning for ethno-racial groupings in the US. ${ }^{2}$ Furthermore, the US is seen as a society that assimilates immigrants by the "melting pot" phenomenon, in which the immigrants are expected to adapt to the American way of life rather than retaining their culture. ${ }^{3}$ Canada has not had the same history of racial segregation and is viewed as a mosaic in which immigrants are encouraged to retain their unique cultural background while partaking in the greater Canadian society. ${ }^{3,6,20}$ Also, Latin Americans comprise a larger component of the US immigrant population than Canada's. ${ }^{2,3}$

The time of arrival and ethnic composition of the immigrant population in the UK and Canada also differ. Up to 1962, citizens of previously colonized countries such as Jamaica and India (countries that remained within the Commonwealth) were granted open access and actively recruited for

\section{Author References}

1 Department of Mental Health, Johns Hopkins Bloomberg School of Public Health, Baltimore, Maryland

2 Department of Psychiatry, University of Toronto, Toronto, Ontario

3 Graduate Department of Public Health Sciences, University of Toronto

4 Toronto Rehabilitation Institute, Toronto, Ontario

5 Department of Occupational Science and Occupational Therapy, University of Toronto

6 Department of Rehabilitation Sciences, University of Toronto

7 Suicide Studies Unit, St. Michael's Hospital, Toronto, Ontario

8 Inner City Health Research Units, St. Michael's Hospital

9 Institute for Clinical Evaluative Sciences, Sunnybrook \& Women's College Hospital, Toronto, Ontario

Correspondence: Diana E Clarke, Department of Mental Health, Johns Hopkins Bloomberg School of Public Health, Room 802 , 624 N Broadway, Baltimore,

MD 21205, Tel : (410) 955-0416, Email: dclarke@jhsph.edu 
immigration to the UK. ${ }^{21}$ During this time, Canada's immigrant population came primarily from Europe, the UK and the US. ${ }^{22,23}$ Post-1971, when the UK changed its immigration act, the majority of its immigrant population originated from Europe and South Africa, ${ }^{21}$ while the majority of Canada's immigrants came from Asia, Africa, the Caribbean, Latin America and the Middle East. ${ }^{23-26}$ These points indicate that results based on UK and/or US data might not be applicable to Canada.

With respect to the operationalization of ethnicity, variations exist across the literature on ethnicity and mental health. Lack of a clear definition of ethnicity and ongoing debate regarding how the variable should be conceptualized might account for this. ${ }^{27,28}$ Other factors such as data source used, feasibility, time period of data collection, region of study and sample size also affect the operationalization of the variable. To date, there is no seminal Canadian paper that discusses the methodological issues related to the definition, conceptualization and operationalization of ethnicity and their implications, to guide future research and to enable comparability across studies. This paper provides a critical review of the original empirical Canadian studies on ethnicity and mental health with emphasis on these issues. A general overview of the definition and conceptualization of ethnicity is first provided to guide the review process. Quantitative studies involving populationbased data with more than one ethnic group are highlighted.

\section{Methods}

The bibliographic databases Sociological Abstracts, PsycINFO, MEDLINE and CINAHL were used to identify relevant original empirical studies that were quantitative in nature for this review with the application of Group 1 and 2 search terms outlined in Figure 1. Studies were included if they: 1) concerned ethnicity and mental health; 2) involved data on
Canadians; 3) involved more than one ethnic group; 4) were published between January 1980 and December 2004; and 5) were quantitative in nature.

General review articles and chapters on the theories and definition of ethnicity, not specific to Canada, were used to provide an overview on the definition and conceptualization of ethnicity. As well, they guided the critique of the identified studies on ethnicity and mental health reviewed herein. Articles on ethnicity and immigration policies specific to Canada were used to provide historical context to facilitate understanding of the ethnic composition of the Canadian population over time and its impact on the studies reviewed.

\section{Results}

After all duplicates were removed, 49 empirical quantitative studies that involved two or more ethnic groups were identified and included in this review (Figure 1) and summarized in Appendix 1. Twenty-seven studies $^{2,5,29-53}$ were based on population or community surveys with secondary data analysis, 12 were smaller studies using nonclinical samples s4-65 $^{5}$ and 10 were smaller studies based on clinical/specialized samples. ${ }^{66-75}$ The year and region of publication, sample size, ethnic groups included and critique regarding the definition of ethnicity are outlined in Appendix 1.

\section{Discussion}

\section{Definition}

The lack of consensus on the definition of ethnicity ${ }^{20,76-80}$ was reflected in the 49 included Canadian studies on ethnicity and mental health, 2,5,29-75 which failed to explicitly define the variable. There are two major perspectives on how ethnicity emerges: the primordialist and constructivist views..$^{20,76,81}$ Traditional primordialists view ethnicity as "an ascribed status, given at birth, that is more or less fixed and permanent." ${ }^{20,76,81-85}$ Accordingly, the individual's identity includes the biological, cultural, political and economic conditions of the group into which s/he is born, be it dominant over, or dominated by, other groups. ${ }^{20,78,81,84}$ A softer primordialist view stresses the social and non-biological basis of ethnicity, acknowledging that ethnic identity can also be socially constructed and based on "the circumstances at hand" thereby being "situational not biological" and "flexible not fixed." view ethnicity as "a social construction with ecological and social factors being its key determinants."12,24-26 Kaufman ${ }^{85}$ stated that distinction between the two perspectives is artificial, so the definition of ethnicity should include a synthesis of both. Hence, the underlying theme is that ethnicity involves sharing of a common culture, which may be based on a combination of factors such as language, religion, national identity, customs, social and/or political position within a country's social system. ${ }^{81}$

\section{Conceptualization}

There are two major perspectives on how ethnicity is conceptualized: 1) ethnic identity which refers to self-identification with particular cultural group/s,,$^{20,76,80,81}$ or 2) ethnic origin which refers to classification due to the ethnic or cultural groups to which the individual's ancestors belong. ${ }^{20}$ Specific cultural traits such as language, surnames, or region of birth were used as proxies for ethnic origin in some studies.

From a Canadian perspective, the country's policy on multiculturalism, which has guided government policies since 1971 and advocated for individuals to retain their ethno-cultural background, ${ }^{8}$ dictates that ethnicity comprised "ethno-cultural particularism" and adherence to Canadian "values." ceptualization of ethnicity across national surveys, which forces participants to identify with their ancestral background regardless of time in Canada. As well, this policy accounts for the designation of all non-Aboriginal persons who originate 


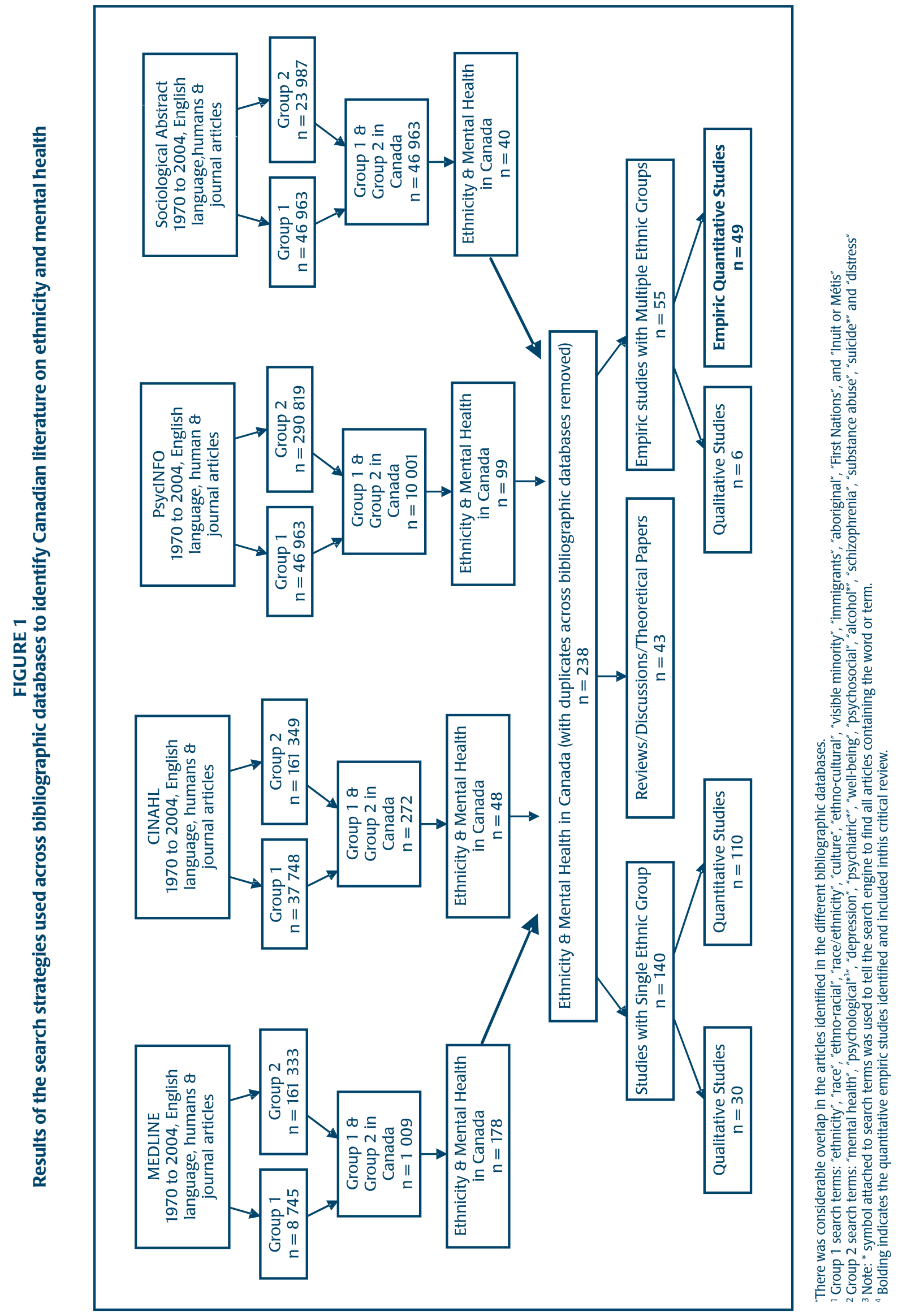


from Africa, Asia, the Caribbean, Latin America and the Middle East, "who are non-Caucasian in race or non-white in colour" as visible minorities. ${ }^{1,3,6}$

\section{Conceptualization based on Ethnic Identity}

Ethnic identity can be internal or external. ${ }^{20,78}$ Internal ethnic identity refers to the individual's self-identification with specific ethnic group/s. ${ }^{78,86,87}$ This conceptualization reflects the individual's level of adherence to and identification with the values, customs and ideologies of a particular culture, ${ }^{87}$ which can be internally or externally driven. ${ }^{78,86-89}$ Individuals may choose to identify with particular ethnic group/s because of their belief in the customs, norms and ideologies and the meaning such identification gives to their life (i.e. internally driven). However, circumstances in the individuals' external environments, such as discrimination based on ethnicity and the feeling of being different from the ethnic majority, may cause some to self-identify with particular ethnic groups because of the sense of solidarity and belonging they may garner from such groups (i.e. externally driven). ${ }^{78,80,87}$

Since external ethnic identity relates to categorization by others based on the person's nationality or ethnic origin and does not reflect the individual's adherence to and/or identification with specific culture $/ \mathrm{s},{ }^{15}$ it is discussed in the context of ethnic origin in the ensuing section. Such external assignment of ethnicities to individuals by the dominant society might conflict with their subscription and adherence to particular ethnic groups and is potentially distressing. This was illustrated by Mahtani ${ }^{6}$ in her interview with Canadian-born visible minority mixed-racial women who often feel forced by the ethnic majority to identify their ancestral background when asked about their ethnic identity (i.e. by the question, “but where are you from?").
A major weakness with self-identification of ethnicity is that it is based on the individual's perception, which may change from situation to situation and over time and likely produce different results depending on the time and research question being investigated. ${ }^{27,28}$ This possibly accounted for the lack of conceptualization of ethnicity based on ethnic identity across studies, with the exception of the respective studies of De Wit et al., ${ }^{40}$ De Wit and Beneteau, ${ }^{41,42}$ and Feldman et al..$^{43}$ De Wit et al. ${ }^{40-42}$ conducted secondary data analysis on the 1990 Ontario Health Survey in which respondents were asked to select up to four ethnic categories that matched their "ethnic or cultural identity." De Wit and Beneteau ${ }^{41,42}$ further utilized information on the primary language that respondents used at home to help "better identify ethnic groups." If respondents identified French or Frenchplus other ethnic groups but did not select French as their primary language they were reclassified as Anglophones ${ }^{41,42}$ indicating externally driven classification of ethnic identity. This externally driven classification of ethnic identity might have been in conflict with the individual's true ethnic identity. If level of adherence to particular cultural values, customs and ideologies are important in the individual's perception of, and subsequent likelihood to acknowledge, discuss or report a mental health condition, and this is a key issue being investigated, then the use of ethnic identity would provide more appropriate information. Feldman et al. ${ }^{43}$ used the item, "Please write down the term that best describes the ethnic character of your everyday home environment," which implies an ethnic identity conceptualization of the variable.

\section{Conceptualization based on Ethnic Origin}

Ethnic origin refers to categorization of individuals into ethnic group/s based on ancestral origins. ${ }^{78}$ The question "To which ethnic or cultural group/s do your ancestors belong?" has been used to capture ethnic origin. ${ }^{90,91,84,95}$ This method of conceptualization is reportedly more objective and produces well-defined ethnic groups that are representative of the population, but fails to capture level of adherence with cultural ideologies or customs. ${ }^{27,92,93}$

Conceptualization of ethnicity based on ethnic origin was observed in some Canadian studies on ethnicity and mental health, particularly those that used national or regional survey data, $2,5,31,32,35,46-48,52$ including the National Population Health Survey (NPHS), ${ }^{90}$ Canadian Community Health Survey (CCHS), ${ }^{91}$ National Longitudinal Survey of Children and Youth (NLSCY), ${ }^{94}$ National Survey of Giving, Volunteering and Participating (NSGVP) ${ }^{95}$ and the 1971 Aging in Manitoba (AIM) survey. ${ }^{31}$ Each survey inquired about the ethnic or cultural group/s of the individuals' ancestors and provided a list of ethnic categories to enable multiple choices..$^{90,91,94,95}$ This acknowledged the existence of multiethnic groups, which are typical of Canada, ${ }^{8}$ and improved the reliability of the groups identified. ${ }^{27}$ Reflective of the emphasis of the country's multiculturalism policy, survey respondents who identified themselves as "Canadian" were required to select their ancestral origin even if they were Canadian-born.

\section{Specific Cultural Traits as Proxies for Ethnic Origin}

One might assume that studies utilizing data from surveys in which ethnicity was based on ethnic origin would conceptualize ethnicity accordingly; however, this was not the case. $\mathrm{Ali}^{5}$ and $\mathrm{Ma}^{47}$ used country of birth in thinking about ethnicity despite utilization of the $\mathrm{CCHS}^{91}$ and the NLSCY ${ }^{94}$ data respectively, both with specific ethnicity questions. The rationale for using country of birth rather than responses to the ethnicity questions was not provided but likely due to the use of public-use data. Public-use versions of Canadian national surveys are readily available to researchers 
but are stripped of unique identifying information and lack the detailed information on ethnicity and culture available in the restricted-use versions.

Penning ${ }^{32}$ utilized the Social Change in Canada Survey (SCCS) data, in which country of birth was used to determine ethnicity. Ascertainment of ethnicity based on country of birth in the study pinpoints an inherent limitation with conducting secondary data analyses where one has to make do with whatever variables are available. With this in mind, it is still important to mention that with increasing global industrialization and migration it has become inappropriate to use country/ region of birth as the sole indicator of ethnicity. Individuals might have been born in one country to parents from another country, spent only a few years in that country and returned with their parents to the countries of their ancestral background thus choosing to identify with their ancestral culture. Therefore, country/ region of birth, also utilized by Ali, ${ }^{5}$ Barnes et al., ${ }^{35} \mathrm{Ma},{ }^{47}$ Cohen and MacLean, ${ }^{51}$ Rousseau et al. ${ }^{53,61}$ and Aubert et al., ${ }^{65}$ would inaccurately classify such individuals. Most countries are comprised of many ethnic groups and most ethnic groups can be found to have many different countries of birth. Country of birth as a proxy for ethnic origins fails to capture such complexities and likely misclassifies some people. This does not negate the use of country/region of birth as a proxy for ethnicity but it underlines the need for detailed discussions of the inherent limitations of its use and implications for the interpretation of subsequent results.

Language and surname were proxies for ethnic origin in some studies ${ }^{37,54-59}$ but are susceptible to misclassification of some individuals. The utilization of surnames to identify ethnic groups by Dion and Giordano $^{57}$ in their investigation of ethnic difference in depression in university students in Toronto, failed to correctly classify non-white/non-Caucasian individuals with non-ethnic last names. If specific ethnic groups were more likely to have individuals with non-ethnic surnames, for example Blacks from the Caribbean and South Asians of Christian descent, ${ }^{57}$ and these individuals were more or less likely to have depression, their exclusion would have biased the results obtained. Bagley ${ }^{58}$ also used surnames and language, but in combination with an unspecified "ethnicity" question to conceptualize ethnicity. Surnames were initially used to identify Chinese elderly persons living in Calgary, Alberta, with follow-up phone calls by the study recruiters who identified eligible Cantonese-speaking individuals and inquired about their ethnicity. This combination of factors overcame the shortcomings of using surnames alone.

Walter $^{37}$ and Dion ${ }^{59}$ used language as a proxy for ethnicity, which might have accurately classified some ethnic groups but not others (e.g. Chinese for individuals who specified Chinese dialect). The English-speaking population is ethnically heterogeneous, with English being the primary language for many countries, so treating the group as homogenous is erroneous. ${ }^{59}$ Also, although French and Spanish are primary languages for France and Spain respectively, they are also the primary languages for some countries in the Caribbean and Africa. The assumption that all individuals who endorsed these languages are of European descent would be inaccurate. ${ }^{59}$ Different ethnic groups may speak the same language or there may be language differences within ethnic groups, which would not be captured with language as the sole proxy for ethnic origin.

\section{Ethnicity, Race or Ethnicity plus Race}

In examining the studies by Weekes, et al. ${ }^{71}$ and Cohen and McLean, ${ }^{51}$ respectively, it became apparent that categorization was based on race, despite the use of the term "ethnicity". Also, the researchers ${ }^{51,71}$ implied that race and culture were the same concepts despite numerous theoretical articles indicating otherwise. ${ }^{28,76-79,85-99}$ To illustrate, Cohen and McLean ${ }^{51}$ utilized data from the 1999 General Social Survey (GSS) in which respondents were asked about their "cultural or racial backgrounds" 96 and Weekes and colleagues ${ }^{71}$ expressed interest in examining the "cultural sensitivity" of their outcome scale. Ethnicity refers to mutual cultural characteristics such as religion, language, customs, and ancestry, ${ }^{20,76,78}$ but race refers to common physical characteristics. ${ }^{28,65,78,86-}$ 101 Winker, $^{28}$ Williams $^{77}$ and LaVeist ${ }^{97}$ stressed the importance of differentiating race from ethnicity or culture. Race is a poor proxy for ethnicity despite overlapping features $^{28,97}$ and is questionable as its sole indicator in respective studies by Fry and Grover $^{54}$ and Devins et al. ${ }^{74}$

$\mathrm{Wu}$ et $\mathrm{al}^{2}$ used ethnic origin and racial background to create ethno-racial groups. This enabled the identification of visible minority groups ${ }^{2}$ and acknowledged the argument that power and status differences also exist across racial groups. ${ }^{77}$ This is important since "the dominant or minority status of the group mirrors its position within the stratification system of the larger society," 101 which in turn affects access to social, political, and economic resources. ${ }^{3,4,101}$ The authors ${ }^{2}$ explained that their ethno-racial groups reflected the social stratification of the Canadian society (i.e. the vertical mosaic),,$^{2-4,7,8}$ which provided a context that facilitated interpretation of results obtained. The vertical mosaic refers to the hypothesis that ethnic groups are differentially integrated in the larger Canadian society based on histories of immigration policies that were linked to changing industrial and employment demands over time..$^{2-4,7,8}$ This differential integration into the Canadian society affected the groups' socioeconomic status, ${ }^{2-4}$ which is significantly associated with mental health outcomes.

\section{Summary}

The identified studies appeared to have conceptualized ethnicity on the basis of ethnic origin by using ethnicity questions, cultural traits as proxies for ethnic origin, or a combination of ethnic origin and racial background. For some studies, although the term "ethnicity" was used it was unclear how it was conceptualized and ascertained. ${ }^{30,33,34,54,55,70,75}$ The intrinsic weaknesses of using proxy measures such as country of birth, language or surnames underline the need for ethnicity to be ascertained using rigorously tested and validated questions. Questions aimed at 
capturing ethnic identity or ethnic origin are unable to tell which aspect of ethnicity the individual brings forward in response during an interview and whether this might be affected by the interviewer and/ or by the specific question being asked. ${ }^{76}$ This highlights the need for clear and theoretically driven rationales for studying ethnicity across mental health outcomes.

\section{Operationalization}

The operationalization of ethnicity is important for interpretation of study results and enabling cross-study comparison. However, variations existed in the operationalization of ethnicity across studies. Even studies that utilized the same data sources and conceptualized ethnicity similarly operationalized the variable differently. Factors that influenced this included diversity of the study population, time period and region of data collection, sample size restrictions and purpose of the study. The effects of these issues are discussed in the ensuing sections.

\section{Time Period of Data Collection and Study}

Time period of data collection and study influenced the operationalization of ethnicity across studies. Time period of data collection is related to changes in the immigration policy over time, which were influenced by economic changes that dictated labour shortages and the need for immigrants to fill specific employment opportunities. ${ }^{20,102} \quad$ Canada's earlier immigration policy was based on national origin and gave preference to immigrants from Britain, Europe and the US to fill such occupational demands. $22,25,103-105$ Hence, immigrants from these regions represented approximately $95 \%$ of Canada's immigrant population up to $1986^{22,25}$ and studies using data collected at this time had little or no representation of other ethnic groups. ${ }^{29,31,32,35,66,67}$

The 1967 change to a universal point system was the force behind the increased ethnic diversity of the Canadian population, with European immigrants comprising
$57 \%$ of immigrants in 1970 but only $20 \%$ in $1996 . .^{22,105}$ Changes in the ethnic composition of the immigrant population occurred gradually with small numbers from Africa, Asia, the Caribbean, Latin America, and the Middle East initially before their proportions increased significantly over time. ${ }^{22,24,25,102,105,106}$ This was reflected in the 3 to $5 \%$ representation of these immigrants in Canada up to the 1980 s compared to their $73 \%$ representation between 1996 and 2001. ${ }^{107}$ Variations in the proportions of these immigrant groups relative to each other and to immigrants from Britain, the US and Europe were reflected in studies conducted with ethnicity data collected over the years. Earlier studies had little or no visible minority groups ${ }^{29,31,35,66,67}$ but their numbers increased in later studies. ${ }^{2,5,35,38,43,46-49,53,61-63}$ Whether these groups were kept as separate categories depended on the outcome of interest and the nature of the study (i.e. secondary data analysis using public-use data that lacked detailed ethnicity information). In the investigation of rare outcomes, such as some mental health conditions, small sample sizes for specific visible minority ethnic groups resulted in them being collapsed into a single category, which likely failed to capture the individuals' perception of their ethnic identity. This also limited the interpretation of the results of such studies.

\section{Region of Data Collection and Study}

Variations in settlement patterns of different ethnic groups in Canada resulted in different ethnic compositions across geographic regions. This affected the operationalization of ethnicity as it relates to the region of data collection and study. Settlement patterns of immigrant groups have always been related to the location of employment opportunities, which were dictated by economic changes over time. ${ }^{78,102}$ Earlier immigrants from Britain, Europe and the US ${ }^{106}$ came to Canada in response to the rapid expansion of the Canadian West with integration of the region with the domestic and world markets and international demand for wheat. ${ }^{78}$ Therefore, many earlier immigrants settled in rural areas of Western
Canada to fill the demands for laborers and farmers. ${ }^{66,102}$ Studies conducted in Western Canada (e.g. Manitoba, ${ }^{31,35,70}$ Alberta $^{66}$ and the Northwest Territories ${ }^{67}$ ) werelikely to havesignificant representation of British, European, North American and Aboriginal ethnic groups but almost no representation of visible minority groups.

Later immigrants from Asia, Africa, the Caribbean, Latin America and the Middle East were more likely to settle in Montreal, Toronto and Vancouver ${ }^{102,108}$ because of their perception of better employment opportunities that corresponded to their skills and educational background. ${ }^{102}$ Supportive data showed that only $58 \%$ of recent immigrants settled in these areas in 1981 but the percentage rose to $78 \%$ by $2001 .^{102}$ Recent studies based on data that includes these three regions had varying proportions of visible minority ethnicities. . $^{2,532,43,44,46-51,53-55,57-63,65,72,74,75}$ Reliance on public-use data prevented examination of very specific ethnic categories because of the inaccessibility of such detailed information.

\section{The Purpose of the Research Study}

As seen in the respective studies of Barnes et al., ${ }^{35}$ Lavallee and Bourgault, ${ }^{45}$ Seltzer and Langford, ${ }^{67}$ and others, ${ }^{29,30,34,37,50,51,58,61,64}$ $, 66,69,70,73,75$ there is flexibility in whether broad or specific categories are used when operationalizing ethnicity in descriptive or enumerative studies as long as they reflect the ethnic composition of the population under investigation. ${ }^{20}$ However, the use of specific ethnic categories is more informative. ${ }^{20}$ For analytic studies, operationalization of ethnicity needs to be theoretically driven to provide a framework for the analyses and interpretation of the results. ${ }^{20}$ Operationalization of ethnicity in the analytic studies reviewed in this paper $^{2,5,31,32,36-43,45-49,52,58,59,75}$ appeared to be based on the social stratification system in Canada, though not always explicitly stated.

Studies interested in examining the mental health status or outcome in specific ethnic groups tended to be clear in their selection and ascertainment of those groups but often aggregated all other ethnic 
groups..$^{30,31,33,34,36,38-42,44,45,51,54,61,67-71}$ For example, Fry and Grover $^{54}$ were interested in examining mental health outcomes in Asians compared to Caucasians and therefore only included these groups. Liban and Smart, ${ }^{30}$ Tonkin, ${ }^{34}$ Beiser et al., ${ }^{39}$ Borzecki et al., ${ }^{68}$ Tcheng-Laroche and Prince $^{33}$ and Dewit and Beneteau, ${ }^{35,42}$ in their studies, were mainly interested in the mental health of Native Indians $s^{30,34,39,68}$ and Francophones $^{33,41,42}$ respectively and therefore selected these groups specifically while aggregating all other ethnicities in the comparison groups.

Havens and Chappell, in investigating the effects of age, sex and ethnicity on mental health in Manitoba, included North American, British, French, Polish/Russian/ Ukrainian and 'Other European' ethnic groups. ${ }^{31}$ These groups were reflective of the time period and region of study. North Americans, British and French were among the earlier immigrants admitted to Canada to fill occupational demands based on the country's immigration policy at that time. The 'Other European' group, which included immigrants from Germany, Norway, Denmark, Sweden, Iceland, the Netherlands and Belgium, ${ }^{31}$ was granted entry into Canada over the Polish/Russian/ Ukrainian when the demand for more immigrants arose. 22,106 After World War II and prior to the change to the universal points system immigration policy, immigrants from Poland, Russia, the Ukraine and other Eastern European countries were admitted to Canada to help survivors of the Nazi Holocaust and to fill specific occupational roles. ${ }^{22,106}$ Therefore, the ethnic groups included in the study ${ }^{31}$ were incorporated into the social hierarchy of Canada at different levels and different points in time, emphasizing the segregation of the Canadian society along ethnic lines. ${ }^{22,104}$ Aboriginal peoples also contributed to the ethnic diversity of Manitoba's population, specifically its rural regions, ${ }^{109}$ but were excluded from the study to "reduce cultural bias". ${ }^{11}$ This statement implied that cultural aspects of ethnicity were important in mental health functioning and needed to be kept constant across groups. It further implied that either the ethnic categories included in the study were culturally similar to each other yet different from Aboriginal peoples or that the individual ethnic groups that comprised each broader ethnic category were culturally similar but the individual ethnic groups that comprised the broader Aboriginal category were too culturally dissimilar to be combined.

Penning ${ }^{32}$ included similar ethnic groups as Havens and Chappell ${ }^{31}$ in examining the same hypothesis with psychosocial wellbeing as the outcome and using a nationally representative sample of Canadians aged 30 and over. The groups also mirrored the social stratification of the Canadian society. Havens and Chappell, ${ }^{31}$ but not Penning, ${ }^{32}$ found ethnic differences in mental health functioning with a "triple jeopardy" effect of age, sex and ethnicity. Methodological issues related to differences in the definition and ascertainment of the mental health outcomes, the conceptualization (e.g. use of country of birth ${ }^{32}$ versus a specific ethnicity question ${ }^{31}$ ) and operationalization of ethnicity, the ethnic and age composition of the study populations, and the regions of study likely played a role in the discrepancy observed.

Since Penning ${ }^{32}$ used country of birth to ascertain ethnicity and mentioned no excluded ethnic groups, it is assumed that Aboriginal peoples and any Canadian-born visible minority individuals, though minimal, were included into the Canadian group. This would make the Canadian group heterogeneous and different from those included in the North American group in Havens and Chappell..$^{31}$ Also, since Penning ${ }^{32}$ utilized data from a national survey, the ethnic category 'Other' probably comprised participants who were members of Canada's visible minority groups whereas these groups were excluded by Haven and Chappell ${ }^{31}$ because of small sample size. Penning, ${ }^{32}$ separated Canadians and Americans while combining immigrants from France, Germany, Norway, Denmark, Sweden, Iceland, the Netherlands and Belgium into a Northern
European group. These factors affected the ability to compare the results of the two studies.

Understanding the mental health of Canada's immigrant population in terms of depression and alcohol dependency was the aim of the study by Ali..$^{5}$ Ethnic differences were examined as a secondary objective in the immigrant group only. ${ }^{5}$ Using region of birth, the ethnic groups examined (i.e. US/Mexico, South and Central America and the Caribbean, Europe, Africa and Asia) mirrored the variation in time of entry into Canada by the different immigrant groups and their differential incorporation in the social hierarchy of the country. This provided a framework for analyses and interpretation of the results. Disaggregation of only the immigrant group based on ethnicity implied that either the investigation of ethnic variation in mental health was only important for immigrant groups and not Canadian-born or all Canadian-born individuals had similar experiences that potentially affected their mental health. Since the Canadian-born group probably had many first generation Canadians who likely had similar experiences as their immigrant parents, these assumptions were likely inaccurate. Given the report of poor mental health in Canada's Aboriginal population, ${ }^{8}$ combining them into the Canadian-born group might not be appropriate. The use of region of birth has numerous drawbacks that could have potentially biased the results obtained but was likely used because of the lack of ethnicity-related information in the publicuse version of the CCHS Cycle 1.1 dataset, which is assumed to be the data source used by Ali. ${ }^{5}$

In examining behavioural and emotional problems in immigrant versus nonimmigrant children in Canada, $\mathrm{Ma}^{47}$ considered ethnicity relevant but only for the immigrant group. Immigrant children were disaggregated into ethnic groups based on region of birth, including those from the US, Europe, Asia and other regions $^{47}$ possibly due to the use of the 
public-use version of the NLSCY. ${ }^{94}$ These ethnic categories differed from $\mathrm{Ali}^{5}$ despite the same method of conceptualizing ethnicity. The studies tested different hypotheses, and were interested in different populations and different outcomes, which affected the ability to compare results across studies.

Beiser et al. ${ }^{46}$ utilized NLSCY ${ }^{94}$ data to examine familial poverty and emotional and behavioural problems in immigrant children versus Canadian-born and included ethnicity as a control variable. Unlike $\mathrm{Ma},{ }^{47}$ ethnicity was examined in the entire sample ${ }^{46}$ thereby eliminating the ambiguities observed in interpreting the results of the former studies. Although the study utilized a data source in which various ethnic categories were available, ethnicity was operationalized by using four broad categories including White/European, Asian, Black and Other. ${ }^{46}$ This implied an interest in, or expectation of, an effect based on visible minority status. The NLSCY included Aboriginal peoples living offreserves, ${ }^{94}$ and since there was no explicit indication of their exclusion, it is assumed that they were either combined in the 'Other' category or included in the 'White/ European' category. The appropriateness of the inclusion of Aboriginal children into either category is questionable given major cultural and social differences.

The NSGVP 95 was utilized by Mata $^{48}$ to investigate satisfaction with life in Canada across ethnic groups and to test the hypothesis that any variations could be explained by ethnic differences in socioeconomic status (SES). Nineteen mutually exclusive ethnic categories were derived for the study with sample size limitations being integral in the collapsing of different ethnic groups into broader categories (e.g. 'Black', 'South Asian', 'Italian' and 'Portuguese' ethnic groups collapsed into 'Black/South Asian' and 'Italian/Portuguese'). ${ }^{48}$ The distinction between certain other ethnic categories was unclear. For instance, the categories 'European', 'Italian/Portuguese', 'German', 'French' 'Ukrainian', 'Polish', etc., all of definite European origin were used without the provision of a clear rationale. This combination of specific and broad ethnic categories without rationale limited the interpretation and comparability of the results. It would have been beneficial if the ethnic categories were guided by a theoretical framework so as to provide more meaning to the results and decrease the observed ambiguity. ${ }^{20}$

Wu et $\mathrm{al}^{2}{ }^{2}$ tested the hypothesis that ethnic differences in depression could be explained by variations in SES and access to social support resources (1996 NPHS ${ }^{90}$ data). The included 'ethno-racial' groups were 'East/ Southeast Asian', 'Chinese', 'South Asian', 'Aboriginal', 'Black', 'Arabic/West Asian', 'Latin American', 'Jewish', 'French', 'English', 'Other Whites', and 'mixed racial', were "representative of the social stratification of the Canadian society" and reflected differences in SES and access to social support resources. ${ }^{2}$ The partial disaggregation of the Asian group into 'East/Southeast Asian' and 'Chinese' was likely due to the overwhelming presence of 'Chinese' (approximately 56\%) in the group, which would have obscured the interpretation of any association with depression. A clear rationale for this partial disaggregation was not provided but left to the readers to assume. Lack of sufficient sample size prevented the disaggregation of other ethnic groups including Blacks and South Asians. ${ }^{2}$

Wang and El-Guebaly ${ }^{52}$ used a 'White' versus 'non-White' dichotomy in operationalizing ethnicity despite the utilization of the 1996 NPHS $^{90}$ data. This was likely due to the use of the public-use version of the survey data, though not explicitly stated. This dichotomy, although handy in separating visible minorities from the ethnic majority, has been criticized for its inadequacy in giving a clear view of ethnic differences in mental health. ${ }^{2,27,104}$ Refinement is needed to account for cultural and/or ecological differences within such broad ethnic groups, ${ }^{104}$ which might include cultural biases in reporting mental health issues. Although the specific ethnicities within the broad 'non-White' group are distinct from each other in languages, histories, customs and social mobility, ${ }^{2}$ discrimination in educational and occupational opportunities based on visible minority status ${ }^{2,22,103,109}$ lends some support to combining the groups into this category. The use of such a broad ethnic category is appropriate if the researchers were asserting that it is the common experience of being 'non-White' that impacts mental health above and beyond the effect of cultural differences in individuals' perceptions of, and attitudes towards, mental health problems, but this was not stated. ${ }^{98}$

Dion and Giordano included 'AngloCeltics', 'North European', 'South European', 'East European', 'East Asian', and 'South Asian' in their study. ${ }^{57}$ These ethnic groups were said to parallel the ethnic composition of the University of Toronto population in $1988^{57}$ and reflected variations in immigration experiences, entrance status and adaptation to life in Canada with respect to parental conflicts, and the likelihood to perceive economic discrimination. ${ }^{57}$ According to the study, 'South Asians' and 'Southern Europeans' were more likely to suffer depression than the 'Anglo-Celtics' and 'Northern Europeans' because of higher likelihood of parental conflict and perceived economic discrimination. ${ }^{57}$ Surnames were used to ascertain ethnicity, ${ }^{57}$ which likely misclassified 'Blacks' and 'South Asians' of Christian background. Since 'South Asian' was an ethnic group of interest in the study, ${ }^{57}$ this misclassification would have likely affected the results obtained by diluting the measure of effect and affected the generalizability of the results to all 'South Asians' in Toronto. The researchers ${ }^{57}$ explained that since an earlier study including 300 students at the same university found less than $3 \%$ indicating West Indian heritage, the potential misclassification by surnames created little or no bias to their results. This inaccurately implied that among 'South Asians' only those of West Indian heritage had nonethnic last names. India's Christian population accounted for about $2.3 \%$ of its total population according to its 1991 and 2001 censuses. ${ }^{110}$

\section{Summary}

In summary, the operationalization of ethnicity in the existing Canadian studies differed depending on how the variable 
was conceptualized, on which data sources were used, on time period and region of data collection, the purpose of the study, and whether the study involved secondary data analysis using public-use versions of national surveys. Some studies tried to disaggregate ethnic categories but were faced with sample size limitations that led to collapsing of distinct ethnic groups while keeping others disaggregated, with no clear rationale. Sample size limitations were found across national survey datasets, particularly for the visible minority ethnic groups, thus underlining the need for future population surveys aimed at providing information on the health and/ or mental health of the Canadian population to over-sample these groups. This would enable the examination of mental health differences across visible minority groups, which is important for the planning of mental health programs to serve Canada's ethnically diverse population.

\section{Conclusions}

This critique of the definition, conceptualization and operationalization of ethnicity across Canadian studies on ethnicity and mental health uncovered a number of key issues that are highlighted below.

a) Ethnicity is a complex and abstract term for which a single and generally accepted definition has not been derived. However, the underlying theme is that it involves the sharing of a common culture. Across studies, ethnicity was not defined a priori, which was likely due to lack of consensus on its definition. Therefore, as suggested by reviewers from the $\mathrm{US}^{28,77,79}$ and UK,,$^{27,92,93}$ clear rationales as to why ethnicity is important to the outcome of interest are necessary.

b) Examination of the relationship between ethnicity and mental health needs to be encouraged with better infrastructure involving improved funding opportuni- ties, given the relevance to the Canadian context. Secondary data analysis is valuable in such research efforts. Therefore, making detailed information on ethnicity more readily available to researchers while maintaining survey participants' confidentiality is vital.

c) Some researchers seemed to have utilized public-use versions of survey data, which hindered their ability to disaggregate ethnic groups due to lack of such detailed information in these files. Their use need to be stated explicitly and their inherent limitations discussed.

d) Ethnicity can be conceptualized based on ethnic origin, ethnic identity, or a combination of ethnic origin and race. Each method has strengths and weakness. Its conceptualization should be theoretically driven and related to the research question of interest. The identified studies conceptualized ethnicity based on ethnic origin, whether through the use of a specific questions or proxy measures such as language, surname or country of birth. Countries of birth, language and surnames are prone to misclassification of certain ethnic groups and biased results if rate of misclassification differed across outcome groups. This does not negate their use as proxies for ethnicity; however, there is a need for researchers to clearly outline their inherent limitations and the implications for the results obtained.

e) Ethnicity based on ethnic origin can be more stable if participants are given a list of ethnic categories with the option of choosing multiple categories. ${ }^{27,93}$ This list should be based on preliminary fieldwork to identify common ethnic categories. An open-ended 'other' option should be included so as not to restrict the individuals' choices. The list should be appended to the research results or made available upon request to enable study replication and to enable readers to ascertain the representativeness of the ethnic categories to the general population.

f) Operationalization of ethnicity varied from very broad to very specific ethnic categories even if ethnicity was conceptualized similarly or the same data source was used. These variations were related to the lack of a clear definition of ethnicity, differences in the time period, region of study and data collection, the purpose of the studies and the utilization of public-use data. Researchers are encouraged to provide a clear outline of the decisions made regarding the data source used (particularly in secondary data analysis), the operationalization of ethnicity, and the categories included in their studies. This will facilitate the interpretation of the results and attempts to replicate the research findings.

g) Differences in the outcomes of interest, how such outcomes were measured and variability in the relevant variables controlled for were additional factors that affected the ability to compare results across studies. Therefore, researchers should clearly define their outcomes of interest and summarize the strengths and weaknesses of the measures used to ascertain outcomes and other relevant variables.

\section{Acknowledgements}

Diana E. Clarke is a Research Associate in the Department of Mental Health at Johns Hopkins Bloomberg School of Public Health and Fellow in Population Health Studies in the Department of Psychiatry at University of Toronto. Dr. Clarke is supported by a Canadian Institute for Health Research Post-doctoral Fellowship Award (Grant \# 200602MFE-159564115967), the Toronto Rehabilitation Institute Foundation and in part by the Population Health Fellowship Award from the Department of Psychiatry at the 
University of Toronto. This study was funded in part by the Ministry of Health and Long-term Care and the Ontario Mental Health Foundation.

\section{References}

1. Statistics Canada. 2001 Census Visible Minority and Population Group User Guide. URL: http://www12.statcan.ca/english/ census01/Products/Reference/tech_rep/ vismin.cfm.

2. Wu Z, Noh S, Kaspar V, Schimmele CM. Race, Ethnicity, and Depression in Canadian Society. J Health Social Behav. 2003;44:426-441.

3. Esses VM, Gardner RC. Multiculturalism in Canada: Context and Current Status. Canadian Journal of Behavioral Science. 1996;28:145-152.

4. Li PS. Social Inclusion of Visible Minorities and Newcomers: The Articulation of "Race" and "Racial" Difference in Canadian Society. Prepared for 2003 Social Inclusion Conference. What Do We Know and Where Do We Go: Building a Social Inclusion Research Agenda. Ottawa, March 27-28, 2003. URL: http://www.ccsd.ca/events/ inclusion/papers/peter_li.pdf.

5. Ali J. Mental Health of Canada's Immigrants. Supplement of Health Reports. 2002;13:1-11

6. Mahtani M. Interrogating the hyphennation: Canadian multicultural policy and "mixed race" identities. In Hier SP and Bolaria BS, eds. Identity and Belonging: Rethinking race and ethnicity in Canadian society. Toronto, Canada: Canadian Scholars' Press Inc, 2006; Chapter 2:31-42.

7. Porter J. The Vertical Mosaic: An Analysis of Social Class and Power in Canada. Toronto: University of Toronto Press, 1965:60-103.

8. Lian JZ, Matthews DR. Does the Vertical Mosaic Still Exist? Ethnicity and Income in Canada, 1991. Can Rev Sociol Anthropol. 1998;35:461
9. Kirmayer $L J$, Minas $H$. The future of cultural psychiatry: An international perspective. Can J Psychiatry. 2000;45:438446.

10. Centers for Disease Control and Prevention. Suicide among Black youths - United States, 1980-1995. MMWR Morb Mortal Wkly Rep. 1998;47:106-193.

11. Shiang J. Does culture make a difference? Racial/ethnic patterns of completed suicide in San Francisco, CA 1987-1996 and clinical implications. Suicide Life Threat Behav. 1998,28:338-354.

12. Joe S, \& Kaplan MS. Suicide Among African American Men. Suicide Life Threat Behav. 2001;Vol.31:S1106-121.

13. Oquendo MA, Ellis SP, Greenwald S, Malone KM, Weissman MM, Mann JJ. Ethnic and sex differences in suicide rates relative to major depression in the United States. Am J Psychiatry. 2001;158:16521658 .

14. Price JH, Dake JA, Kuchareswki R. Assets as predictors of suicide attempts in African American inner-city youths. Am J Health Behav. 2001;25:367-375.

15. O’Donnell L, O’Donnell C, Merrit Wardlaw D, Stueve A. Risk and resiliency factors influencing suicidality among African American and Latino youth. Am J Community Psychol. 2004;33:37-49.

16. Neeleman J, Mak V, Wessely S. Suicide by age, ethnic group, coroners' verdicts and country of birth: A three year survey in Inner London. $\mathrm{Br} \mathrm{J}$ Psychiatry. 1997;171:463-467.

17. Neeleman J, Wessely S. Ethnic minority suicide: A small area geographical study in South London. Psychol Med. 1999;29:429436.

18. Bhugra D, Desai M, Baldwin D. Attempted suicide in west London: Rates across ethnic communities. Psychol Med, 1999;29:11251130.
19. McKenzie K, van Os J, Samele C, van Horn E, Tattan T, Murrau R. Suicide and attempted suicide among people of Caribbean origin with psychosis living in the UK. Br J Psychiatry. 2003;183:40-44.

20. Isajiw WW. Definitions of Ethnicity. Ethnicity. 1974;1:111-124

21. Bell, BD. The Performance of Immigrants in the United Kingdom: Evidence from the GHS. The Economic Journal. 1997;107:333344.

22. Green AG, Green DA. The Economic Goals of Canada's Immigration Policy, Past and Present. Departmet of Economics, University of British Columbia. 1996.

23. Li PS. Race and ethnicity. In Li PS (Ed) Race and Ethnic Relations in Canada, Second Edition. Oxford University Press, Canada. 1999;3-20.

24. Beaujot R. Immigration and Canadian Demographics: State of the Research. Citizenship and Immigration Canada 1998. URL: http://www.cic.gc.ca/english/ research/papers/demographics.html

25. Citizenship and Immigration Canada. Citizenship and Immigration Statistics, 1966-1996. 2004. URL: http://epe.lac-bac. gc.ca/100/202/301/immigration_statisticsef/index.html

26. Belanger A, Malenfant EC. Population projections of visible minority groups, Canada, provinces and regions 2001-2017. Ottawa: Statistics Canada, Demography Division. 2005. Cat. No. 91-541-XIE.

27. Aspinall PJ. Operationalising the collection of ethnicity data in studies of the sociology of health and illness. Sociol Health Illn. 2001;23:829-862.

28. Winker MA. Measuring Race and Ethnicity: Why and How? JAMA. 2004;292:16121614. 
29. Murphy HBM. European cultural offshoots in the New World: Differences in their mental hospitalization patterns. Part II: German, Dutch, and Scandinavian influences. Archiv fur Psychiatrie und Nervenkrankheiten (Archives of Psychiatry and Neurological Sciences). 1980;228:161174.

30. Liban CB, Smart RG. Drinking and drug use among Ontario Indian students. Drug Alcohol Depend. 1982;9:161-171.

31. Havens B, Chappell NL. Triple Jeopardy: Age, Sex, and Etnicity. Canadian Ethnic Studies. 1983;15:119-129.

32. Penning MJ. Multiple Jeopardy: Age, Sex, and Ethnic Variations. Canadian Ethnic Studies. 1983;15:81-105.

33. Tcheng-Laroche F, Prince R. Separated and divorced women compared with married controls: Selected life satisfaction, stress and health indices from a community survey. Soc Sci Med. 1983;17:95-105.

34. Tonkin RS. Suicide methods in British Columbian adolescents. J Adolesc Health Care. 1984;5:172-177

35. Barnes GE, Currie RF, Segall A. Symptoms of Depression in a Canadian Urban Sample. Can J Psychiatry. 1988;33:386-392.

36. Sack WH, Beiser M, Phillips N, BakerBrown G. Co-morbid symptoms of depression and conduct disorder in First Nations children: Some findings from the Flower of Two Soils Project. Cult Med Psychiatry. 1993;16:471-486.

37. Walters, V. Stress, Anxiety and Depression: Women's Accounts of their Health Problems. Soc Sci Med. 1993;36:393-402.

38. Beiser M, Cargo M, Woodbury MA. A comparison of psychiatric disorder in different cultures: Depressive typologies in Southeast Asian refugees and resident Canadians. Int J Methods Psychiatr Res. 1994;4:157-172.
39. Beiser M, Sack W, Manson SM, Redshirt R, Dion R. Mental and the academic performance of First Nations and majorityculture children. Am J Orthopsychiatry. 1998;68:455-467.

40. De Wit ML, Embree BG, De Wit DJ. Determinants of the risk and timing of alcohol and illicit drug use onset among natives and non-natives: Similarities and differences in family attachment. Soc Biol. 1999;46:100-121.

41. DeWit DJ, Beneteau B. Predictors of the prevalence of alcohol use and related problems among Francophones and Anglophones in the province of Ontario, Canada. Journal of the Study of Alcoholism. 1998;59:78-88.

42. DeWit DJ, Beneteau B. Predictors of the prevalence of tobacco use among Francophones and Anglophones in the province of Ontario. Health Educ Res. 1999;14:209-223.

43. Feldman L, Harvey B, Holowaty P, Shortt L. Alcohol use beliefs and behaviors among high school students. J Adolesc Health. 1999;24:48-58.

44. Beiser M, Dion R, Gotowiec A. The structure of attention-deficit and hyperactivity symptoms among Native and Non-Native elementary school children. J Abnorm Child Psychol. 2000;28:425-437.

45. Lavallee C, Bourgault C. The health of Cree, Inuit and Southern Quebec Women: Similarities and Differences. Can J Public Health. 2000; 91:212-216.

46. Beiser M, Hou F, Hyman I, Tousignant M. Poverty, Family Process, and the Mental Health of Immigrant Children in Canada. Am J Public Health. 2002;92:220-227.

47. Ma X. The First Ten Years in Canada: a Multi-Level Assessment of Behavioral and Emotional Problems of Immigrant Children. Canadian Public Policy. 2002;28:395-418.

48. Mata F. A Look at Life Satisfaction and Ethnicity in Canada. Canadian Ethnic Studies. 2002;34: 51-63.
49. Wu Z, Hart R. Social and health factors associated with support among elderly immigrants in Canada. Research on Aging. 2002;24:391-412.

50. Blackstock C, Trocme N, Bennett M. Child maltreatment investigations among Aboriginal and Non-Aboriginal families in Canada. Violence Against Women. 2004;10:901-906.

51. Cohen MM, MacLean H. Violence against Canadian Women. BMC Women's Health. 2004;4:S22.

52. Wang JW, El-Guebaly N. Sociodemographic Factors Associated with Comorbid Major Depressive Episodes and Alcohol Dependence in the General Population. Can J Psychiatry. 2004;49:37-44.

53. Rousseau C, Drapeau A. Premigration exposure to political violence among independent immigrants and its association with emotional distress. J Nerv Ment Dis. 2004;192:852-856.

54. Fry PS, Grover SC. Cognitive Appraisals of Life Stress and Depression in the Elderly: A Cross-Cultural Comparison of Asians and Caucasians. International Journal of Psychology. 1982;17:437-454.

55. Dyal, James A; Chan, Carolina. Stress and distress: A study of Hong Kong Chinese and Euro-Canadian students. Journal of Cross-Cultural Psychology. 1985;16(4):447466.

56. Blandford AA, Chappell NL. Subjective well-being among Native and non-Native elderly persons: Do differences exist? Can J Aging. 1990;9(4):386-399.

57. Dion KL, Giordano C. Ethnicity and Sex as Correlates of Depression Symptoms in a Canadian University Sample. Int $\mathrm{J}$ Soc Psychiatry. 1990;36:30-41.

58. Bagley CR. Mental health and social adjustment of elderly Chinese immigrants in Canada. Canada's Mental Health. 1993;Fall:6-10. 
59. Dion KL. Ethnolinguistic Correlates of Alexithymia: Toward a Cultural Perspective. J Psychosom Res. 1996;41:531-539.

60. Heine SJ, Lehman DR. Culture, SelfDiscrepancies, and Self-Satisfaction. Pers Soc Psychol Bull. 1999;25:915-925.

61. Rousseau C, Mekki-Berrada A, Moreau S. Trauma and extended separation from family among Latin American and African refugees in Montreal. Psychiatry. 2001;64:40-59.

62. Howard LA, Ahluwalia JS, Lin SK, Sellers EM, Tyndale RF. CYP2E1*1D regulatory polymorphism: association with alcohol and nicotine dependence. Pharmacogenetics. 2003;13:321-328.

63. Tweed RG, White K, Lehman DR. Culture, stress and coping: Internally- and externally-targeted control strategies of European Canadians, East Asian Canadians and Japanese. Journal of Cross-Cultural Psychology. 2004;35:652-668.

64. Khanlou N. Influences on adolescent selfesteem in multicultural Canadian secondary schools. Public Health Nurs. 2004;21:404-411.

65. Aubert P, Daigle MS, Daigle JG. Cultural Traits and Immigration: Hostility and Suicidality in Chinese Canadian Students. Trancultural psychiatry. 2004;41: 514-532.

66. Bland RC, Orn H. Schizophrenia: Sociocultural Factors. Can J Psychiatry. 1981;26:186-188.

67. Seltzer A, Langford A. Forensic psychiatric assessments in the Northwest Territories. Can J Psychiatry. 1984;29:665-668.

68. Borzecki M, Wormith JS, Black WH. An examination of differences between native and non-native psychiatric offenders on the MMPI. Canadian Journal of Behavioural Sciences. 1988;20:287-301.

69. Chandrasena R, Beddage V, Fernando MLD. Suicide among immigrant psychiatric patients in Canada. $\mathrm{Br} \mathrm{J}$ Psychiatry. 1991;159:707-709.
70. Norton GR, Rockman GE, Malan J, Cox BJ, Hewitt PL. Panic attacks, chemical abuse and suicidal ideation: A comparison of native and non-native Canadians. Alcoholism Treatment Quarterly. 1995;12:33-41.

71. Weekes JR, Morison SJ, Millson WA, Fettig DM. A comparison of Native, Métis, and Caucasian offender profiles on the MCMI. Canadian Journal of Behavioural Science. 1995;27:187-198.

72. Pawliuk N, Grizenko N, Chan-Yip A, Gantous P, Mathew J, Nguyen D. Acculturation style and psychological functioning in children of immigrants. Am J Orthopsychiatry. 1996;66:111-121 .

73. Zapf PA, Roesch R, Hart SD. An examination of the relationship of homelessness to mental disorder, criminal behaviour, and health care in a pretrial jail population. Can J Psychiatry. 1996;41:435-440.

74. Devins GM, Edworthy SM, Aramis Lupus State Models Research Group. Illness intrusiveness explains race-related qualityof-life differences among women with systemic lupus erythematosus. Lupus. 2000;9:534-541.

75. Hodelet N. Psychosis and offending in British Columbia: characteristics of a secure hospital population. Crim Behav Ment Health. 2001;11163-172.

76. Troper H, Weinfeld M. Ethnicity, Politics and Public Policy: Case studies in Canadian Diversity. Toronto: University of Toronto Press, 1999:3-25.

77. Williams DR. Race and Health: Basic Questions, Emerging Directions. Annual Review of Epidemiology. 1997;7:322-333.

78. Isajiw WW. Understanding diversity: Ethnicity and race in the Canadian Context. Toronto: Thompson Educational Publishing Inc., 1999:17-36.

79. Comstock RD, Castillo EM, Lindsay SP. Four-Year Review of the Use of Race and Ethnicity in Epidemiologic and Public Health Research. Am J Epidemiol. 2004;159:611-619.
80. Trimble JE, Dickson R. Ethnic Identity. In Fisher CB and Lerner RM, eds. Applied developmental science: An encyclopedia of research, policies, and programs. Thousand Oaks: Sage. In press.

81. Allahar A. The social construction of primordial identities. In Hier SP and Bolaria BS, eds. Identity and Belonging: Rethinking race and ethnicity in Canadian society. Toronto: Canadian Scholars' Press Inc., 2006; Chapter 2:31-42.

82. Connor W. Ethnonationalism: The Quest for Understanding. Princeton: Princeton University Press, 1994:89-117.

83. Smith AD. The ethnic origins of nations. New York: Basil Blackwell, 1986:1-20.

84. Van Den Berghe PL. Ethnicity and the sociobiology debate. In Rex J and Mason, $\mathrm{D}$, eds. Theories of Race and Ethnic Relations. Cambridge University Press, 1986:246-263

85. Kaufman SJ. Ethnic fears and ethnic war in Karabagh. Centre for Strategic and International Studies. 1998. URL: www. csis.org/ruseura/pronars/working_papers

86. Cheung YW. Approaches to ethnicity: Clearing roadblocks in the study of ethnicity and substance abuse. International Journal of Addictions. 1993;28(12):12091226.

87. Phinney J. Ethnicidentity and acculturation In Chun K, Organista PB, and Marin G, eds. Acculturation: Advances in theory, measurement, and applied research. Washington, DC: American Psychological Association, 2003:63-81

88. Tajfel H. Social identity and intergroup relations. Cambridge: Cambridge University Press, 1982:207-240.

89. Weinreich P, Saunderson W, eds. Analyzing identity: Cross-cultural, societal and clinical contexts. New York: Routledge, 2003:7-110 \& 115-170 
90. Statistics Canada. National Population Health Survey, Cycle 2. 1996. URL: http:// www.statcan.ca/cgi-bin/imdb/p2SV.pl?Fu nction $=$ getSurvey \&SDDS $=3225 \&$ lang $=\mathrm{e}$ $\mathrm{n} \& \mathrm{db}=\mathrm{IMDB} \& \mathrm{db} g=\mathrm{f} \& \mathrm{adm}=8 \& \mathrm{dis}=2$.

91. Statistics Canada. Canadian Community Health Survey, Cycle 1.1. 2000. URL: http://www.statcan.ca/english/concepts/ health/ .

92. Nazroo JY. Genetic, cultural or socioeconomic vulnerability? Explaining ethnic inequalities in health. Sociol Health Illn. 1998;20:710-730.

93. Nazroo JY. The structuring of ethnic inequalities in health: economic position, racial discrimination and racism. Am J Public Health. 2003;93(2):277-84.

94. Statistics Canada. National Longitudinal Survey for Child and Youth, Cycle 1. 1994. URL: http://www.statcan.ca/cgi-bin/imdb/ p2SV.pl? Function $=$ getSurvey $\&$ SurvId $=44$ 50\&SurvVer $=0$ \&InstaId $=16044 \&$ InstaVer $=1 \&$ SDDS $=4450 \&$ lang $=$ en \&db $=$ imdb\&d $\mathrm{bg}=\mathrm{f} \& \mathrm{adm}=8 \&$ dis $=2$.

95. Statistics Canada. National Survey of Giving, Volunteering and Participating, Cycle 1. 1997. URL: http://www.statcan. ca/cgi-bin/imdb/p2SV.pl?Function = getSur vey\&SurvId $=4430 \&$ SurvVer $=0$ \&InstaId $=1$ 6024\&InstaVer $=1 \&$ SDDS $=4430 \&$ lang $=$ en $\& d b=i m d b \& d b g=f \& a d m=8 \& d i s=2$.

96. Statistics Canada. General Social Survey Victimization. 1999. URL: http://www. statcan.ca/cgi-bin/imdb/p2SV.pl?Function $=$ getSurvey \&SDDS $=4504 \&$ lang $=$ en $\& \mathrm{db}$ $=\mathrm{IMDB} \& \mathrm{dbg}=\mathrm{f} \& \mathrm{adm}=8 \& \mathrm{dis}=2$.
97. LaVeist TA. Beyond Dummy Variables and Sample Selection: What Health Services Researchers Ought to Know about Race as a variable. Health Serv Res. 1994;29:1-16.

98. Yinger JM. Ethnicity: Source of Strength? Source of Conflict? New York: State University of New York Press, 1994:1$67 \& 167-198$.

99. Stolley PD. Race in Epidemiology. Int J Health Serv. 1999;29:905-909.

100. Chaturvedi N. Ethnicity as an epidemiological determinant-crudely racist or crucially important? Int $\mathrm{J}$ Epidemiol. 2001;30:925-927.

101. James CE. Race, ethnicity and cultural identity. In Hier SP and Bolaria BS, eds. Identity and Belonging: Rethinking race and ethnicity in Canadian society. Toronto, Canada: Canadian Scholars' Press Inc., 2006; Chapter 3:43-55.

102. Di Biase S, Bauder H. Immigrants in Ontario: Linking Spatial Settlement Patterns and Labour Force Characteristics. Department of Geography, University of Guelph. 2004. URL: www.uoguelph.ca/ geography/research/ffw/papers/ Settlement\%20in\%200ntario_report.pdf .

103. Ali J, Grabb E. Ethnic origin, class origin and educational attainment in Canada: Further evidence on the mosaic thesis. Journal of Canadian Studies. 1998;32: 3-21.
104. Breton R, Roseborough H. Ethnic differences in status. In Blishen BR et al., eds. Canadian Society. Toronto: Macmillan, 1968:683-701.

105. Thompson EN. Immigrant Occupational Skill Outcomes and the Role of Region-OfOrigin-Specific Human Capital-September 2000. Ottawa: Human Resources Development Canada. 2000. Cat. No. W-00-8E.

106. Wallace M. "Planning Amidst Diversity: The Challenges of Multiculturalism in Urban and Suburban Greater Toronto." PhD Thesis. University of Waterloo, 1999.

107. Beshiri, R. Immigrants in rural Canada: 2001 update. Rural and Small Town Canada Analysis Bulletin. 2004;5:1-27. Cat. No. 21-006-XIE.

108. Schellenberg G. Trends and Conditions in Census Metropolitan Areas: Immigrants in Canada's Census Metropolitan Areas. Statistics Canada. 2004. Cat. No. 89-613MIE - No. 003. URL: http://www.statcan. ca/english/research/89-613-MIE/2004003/ 89-613-MIE2004003.pdf .

109. Manitoba and Northern Affairs. Aboriginal People in Manitoba 2000. URL: http:// www.gov.mb.ca/ana/apm2000/index. html .

110. Office of the Registrar General, India. Proportion and growth rate of population by religious communities - India : 19612001. URL: http://www.censusindia.net/ religiondata/statement.pdf . 


\section{APPENDIX I \\ Quantitative empiric studies on ethnicity and mental health conducted in Canada (or with Canadian data) that included two or more ethnic groups}

$\mathrm{N}=$ Sample size of study, $\mathrm{A}=$ Age range of study individuals, $\mathrm{S}=$ Source(s) of data, $\mathrm{D}=$ Data type, $\mathrm{DA}=\mathrm{Data}$ analyses, $\mathrm{T}=\mathrm{Type}$ of study, DV = Dependent Variable, IV = Independent Variable

\begin{tabular}{|c|c|c|c|c|}
\hline $\begin{array}{l}\text { Author(s), year of } \\
\text { publication \& region } \\
\text { of study }\end{array}$ & $\begin{array}{c}\text { Study Sample } \\
\text { (sample size, data source, age } \\
\text { group included and study design) }\end{array}$ & Ethnic groups included & Outcome Examined & Comments \\
\hline \multicolumn{5}{|c|}{ Studies based on population-based or large community-based surveys/samples $(n=27)$} \\
\hline $\begin{array}{l}\text { 1. Murphy, } 1980 \\
\text { (Canada) }^{29}\end{array}$ & $\begin{array}{l}N=\text { not given } \\
A=15+ \\
S=\text { Dominion Bureau of Statistics reports on } \\
\text { first admissions to Canadian Mental Hospitals } \\
\text { in } 1961 \text { and the } 1961 \text { Population Census. } \\
D=\text { Cross-sectional } \\
D A=\text { Standardized Morbidity Ratio (SMR) } \\
T=\text { Descriptive }\end{array}$ & $\begin{array}{l}\text { German Origin; } \\
\text { Dutch Origin; } \\
\text { Scandinavian Origin; } \\
\text { Canadian-born }\end{array}$ & DV: Mental hospitalizations & $\begin{array}{l}\text { 1. A clear definition of ethnicity not given. } \\
\text { 2. Ethnicity based on "country from which the } \\
\text { individual's ancestors on the male side } \\
\text { came when they settled in Canada", } \\
\text { therefore an ethnic origin conceptualization. } \\
\text { 3. Ethnic groups reflective of the immigration } \\
\text { pattern in Canada during the time period } \\
\text { (i.e. } 1960 \text { 's) }\end{array}$ \\
\hline $\begin{array}{l}\text { 2. Liban \& Smart, } 1982 \\
\text { (Ontario, Canada) }^{30}\end{array}$ & $\begin{array}{l}N=128 \\
A=10 \text { to } 20 \text { (i.e. Grade } 7 \text { to } 13 \text { ) } \\
S=1979 \text { Survey of Alcohol and Drug Use } \\
\text { among Ontario students } \\
D=\text { Cross-sectional } \\
D A=\text { Descriptive and Chi-square analyses } \\
T=\text { Descriptive }\end{array}$ & $\begin{array}{l}\text { Native Indian [64]; } \\
\text { Non-Native Indian [64] }\end{array}$ & $\begin{array}{l}\text { DV: Frequency and problems } \\
\text { with alcohol and drug use }\end{array}$ & $\begin{array}{l}\text { 1. A clear definition of ethnicity not given. } \\
\text { 2. Ethnicity based on cultural background but } \\
\text { how ascertained not specified. } \\
\text { 3. Although cultural background in the survey } \\
\text { included a breakdown into English } \\
\text { Canadian, French Canadian, Asian, Native } \\
\text { Indian and other, the non-Native Indian } \\
\text { categories were aggregated for the study } \\
\text { based on matching. }\end{array}$ \\
\hline $\begin{array}{l}\text { 3. Havens \& Chappell, } \\
1983 \text { (Manitoba, } \\
\text { Canada) }{ }^{31}\end{array}$ & $\begin{array}{l}N=3647 \\
A=65+ \\
S=\text { Aging in Manitoba Survey (1971) } \\
D=\text { Cross-sectional } \\
D A=\text { ANOVA } \\
T=\text { Analytic }\end{array}$ & $\begin{array}{l}\text { North American [370]; British } \\
\text { [1633] } \\
\text { French [216]; Polish/Russian/ } \\
\text { Ukrainian [685]; } \\
\text { Other European (German, } \\
\text { Norwegian, Danish, Swedish, } \\
\text { Icelandic, Dutch, Belgian) } \\
\text { [743] }\end{array}$ & $\begin{array}{l}\text { DV: Perceived well-being, } \\
\text { perceived health status, } \\
\text { mental health functioning }\end{array}$ & $\begin{array}{l}\text { 1. The ethnic groups in the study not } \\
\text { representative of the whole of Canada but } \\
\text { of Manitoba specifically. } \\
\text { 2. Ethnic groups reflective of the immigration } \\
\text { pattern in the province and of the time } \\
\text { period. } \\
\text { 3. Ethnic origin based on ethnicity question in } \\
\text { the survey }\end{array}$ \\
\hline $\begin{array}{l}\text { 4. Penning, } 1983 \\
\text { (Canada) })^{32}\end{array}$ & $\begin{array}{l}N=2253 \\
A=30+ \\
S=\text { Social Change in Canada Survey (1977) } \\
D=\text { Cross-sectional } \\
D A=\text { ANOVA } \\
T=\text { Analytic }\end{array}$ & $\begin{array}{l}\text { Canadian [1720]; American } \\
\text { [57]; British [159]; North } \\
\text { European (France, Germany, } \\
\text { Austria, Scandinavia, } \\
\text { Netherlands) [96]; South } \\
\text { European (Greece, Portugal, } \\
\text { Spain, Italy) [65]; East } \\
\text { European (Russia, Hungary, } \\
\text { Poland) [96]; Others [62] }\end{array}$ & $\begin{array}{l}\text { DV: Perceived psychological } \\
\text { well-being }\end{array}$ & $\begin{array}{l}\text { 1. A clear definition of ethnicity not given. } \\
\text { 2. Some ethnic categories not clearly } \\
\text { explained for example the ethnic group } \\
\text { referred to as "Other". } \\
\text { 3. Ethnic origin based on country of birth. }\end{array}$ \\
\hline $\begin{array}{l}\text { 5. Tcheng-Laroche \& } \\
\text { Prince, } 1983 \text { (Montreal, } \\
\text { Quebec, Canada) }{ }^{33}\end{array}$ & $\begin{array}{l}\mathrm{N}=128 \\
\mathrm{~A}=\text { not given } \\
\mathrm{S}=\text { Community survey of a representative } \\
\text { sample of separated or divorced mothers in } \\
\text { Montreal } \\
\mathrm{D}=\text { Cross-sectional } \\
\mathrm{DA}=\text { Chi-square, ANOVA } \\
\mathrm{T}=\text { Analytic }\end{array}$ & $\begin{array}{l}\text { Francophone [62]; } \\
\text { Anglophone [66] }\end{array}$ & $\begin{array}{l}\text { DV: Psychosocial stress per the } \\
\text { Langner Scale, self-esteem per } \\
\text { the RSE and life satisfaction }\end{array}$ & $\begin{array}{l}\text { 1. A clear definition of ethnicity not given. } \\
\text { 2. Study interested in examining "cultural } \\
\text { effects". } \\
\text { 3. Study included French- and } \\
\text { English-Canadians in Montreal. It is unclear } \\
\text { how being French and/or English-Canadian } \\
\text { were ascertained. }\end{array}$ \\
\hline $\begin{array}{l}\text { 6. Tonkin, } 1984 \text { (British } \\
\text { Columbia, Canada) }^{34}\end{array}$ & $\begin{array}{l}N=122 \\
A=<20 \text { years old } \\
S=\text { Vital statistics data (with follow-up review } \\
\text { of all deaths reported to the provincial Chief } \\
\text { Coroner's office } 1978 / 9 \text { ) } \\
D=\text { Cross-sectional } \\
D A=\text { Descriptive and chi-square analyses } \\
T=\text { Descriptive }\end{array}$ & $\begin{array}{l}\text { Native Indian [33]; } \\
\text { Non-Natives [89] }\end{array}$ & $\begin{array}{l}\text { DV: Suicides and psychiatric } \\
\text { diagnoses }\end{array}$ & $\begin{array}{l}\text { 1. A clear definition of ethnicity not given. } \\
\text { 2. Ethnicity used as a covariate but how it was } \\
\text { ascertained not indicated because it was } \\
\text { abstracted from the coroners' records. } \\
\text { 3. The rationale for the inclusion of ethnicity } \\
\text { as a covariate not explained. }\end{array}$ \\
\hline $\begin{array}{l}\text { 7. Barnes et al., } 1988 \\
\text { (Winnipeg, Manitoba, }_{\text {Canada) }}{ }^{35}\end{array}$ & $\begin{array}{l}N=524 \\
A=18 \text { to } 80 \\
S=1983 \text { Winnipeg Area Study } \\
D=\text { Cross-sectional } \\
D A=\text { ANOVA, } X^{2}, \text { \& multiple classification } \\
\text { analyses } \\
T=\text { Exploratory }\end{array}$ & $\begin{array}{l}\text { English [84]; } \\
\text { East European [62]; } \\
\text { West European [82]; Canadian } \\
\text { [193]; } \\
\text { Other [97] }\end{array}$ & DV: Depression (CES-D) & $\begin{array}{l}\text { 1. Ethnicity examined as a predictor of } \\
\text { depression. } \\
\text { 2. Ethnic groups reflective of the ethnic } \\
\text { composition region of study. } \\
\text { 3. Ethnic origin based on country of birth. }\end{array}$ \\
\hline
\end{tabular}




\begin{tabular}{|c|c|c|c|c|}
\hline $\begin{array}{l}\text { Author(s), year of } \\
\text { publication \& region } \\
\text { of study }\end{array}$ & $\begin{array}{c}\text { Study Sample } \\
\text { (sample size, data source, age } \\
\text { group included and study design) }\end{array}$ & Ethnic groups included & Outcome Examined & Comments \\
\hline $\begin{array}{l}\text { 8. Sack et al., } 1993 \\
\text { (Canada \& US) }^{36}\end{array}$ & $\begin{array}{l}N=1115 \\
A=7 \text { to } 9 \text { (Grades } 2 \text { and } 4) \\
S=\text { Flower of Two Soils Project } \\
D=\text { Prospective and longitudinal ( } 3 \text { year follow- } \\
\text { up) } \\
D A=\text { Correlation analyses, ANOVA, chi-square } \\
\text { analyses } \\
T=\text { Analytic }\end{array}$ & $\begin{array}{l}\text { First Nation children from the } \\
\text { Plains (South Dakota, US), } \\
\text { Northern Woodlands } \\
\text { (Manitoba, Canada), Desert } \\
\text { (New Mexico, US) and Coastal } \\
\text { (British Columbia, Canada) } \\
\text { compared to a sample of } \\
\text { non-Native children at each } \\
\text { site }\end{array}$ & $\begin{array}{l}\text { DV: Depressive symptoms } \\
\text { using new measures of } \\
\text { psycho-pathology and mental } \\
\text { health (the SOS) }\end{array}$ & $\begin{array}{l}\text { 1. No explicit definition given for ethnicity. } \\
\text { 2. Study specifically interested in cultural } \\
\text { differences between the various First Nation } \\
\text { groups across North America, hence it is } \\
\text { implied that ethnicity is based on culture. }\end{array}$ \\
\hline $\begin{array}{l}\text { 9. Walters, } 1993 \\
\text { (Hamilton, Ontario, }^{\text {Canada) }}{ }^{37}\end{array}$ & $\begin{array}{l}N=356 \\
A=21+ \\
S=A \text { stratified random sample of women in } \\
\text { Hamilton } \\
D=\text { Cross-sectional } \\
D A=\text { Chi-square } \\
T=\text { Descriptive }\end{array}$ & $\begin{array}{l}\text { English-speaking vs. other } \\
\text { language }\end{array}$ & $\begin{array}{l}\text { DV: Stress, anxiety and } \\
\text { depression }\end{array}$ & $\begin{array}{l}\text { 1. Ethnic origin based on primary language. } \\
\text { 2. No definition for ethnicity. } \\
\text { 3. Language stated as a possible proxy for } \\
\text { ethnicity. }\end{array}$ \\
\hline $\begin{array}{l}\text { 10. Beiser et al., } 1994 \\
\text { (Vancouver, British }^{\text {Columbia, Canada) }}{ }^{38}\end{array}$ & $\begin{array}{l}\mathrm{N}=1667 \\
\mathrm{~A}=\text { ? } \\
\mathrm{S}=1348 \text { refugees from the Refugee } \\
\text { Resettlement Project and an area-probability } \\
\text { sample of } 319 \text { Vancouver residents matched to } \\
\text { refugees on age and sex } \\
\mathrm{D}=\text { Cross-sectional } \\
\mathrm{DA}=\text { Grade of Membership analysis (GOM: a } \\
\text { multivariate clustering technique) } \\
\mathrm{T}=\text { Analytic }\end{array}$ & $\begin{array}{l}\text { Southeast Asians [1348]; } \\
\text { Resident Canadians [319]; } \\
\text { Southeast Asian group } \\
\text { disaggregated: Chinese [755]; } \\
\text { Vietnamese/Laotian [593] }\end{array}$ & $\begin{array}{l}\text { DV: Psychiatric disorders } \\
\text { including depression, anxiety } \\
\text { and somatization per the } \\
\text { CES-D, DIS and the Senegal } \\
\text { Health Scales }\end{array}$ & $\begin{array}{l}\text { 1. No explicit definition given for ethnicity. } \\
\text { 2. Researchers interested in } \\
\text { "psychopathological expression among } \\
\text { different ethno-cultural groups", therefore } \\
\text { ethnicity based on culture. } \\
\text { 3. Ethnicity based on where the individual } \\
\text { emigrated from. }\end{array}$ \\
\hline $\begin{array}{l}\text { 11. Beiser et al., } 1998 \\
\text { (Canada \& US) }\end{array}$ & $\begin{array}{l}N=1708 \\
A=7 \text { to } 9 \text { (Grades } 2 \text { and } 4 \text { ) } \\
S=\text { Flower of Two Soils Project } \\
D=\text { Prospective and longitudinal } \\
D A=\text { Principal component factor analysis on } \\
\text { the psychopathology measure, correlation } \\
\text { analyses, ANOVA, chi-square analyses } \\
T=\text { Analytic }\end{array}$ & $\begin{array}{l}\text { First Nation children from the } \\
\text { Plains (South Dakota, US), } \\
\text { Northern Woodlands } \\
\text { (Manitoba, Canada), Desert } \\
\text { (New Mexico, US) and Coastal } \\
\text { (British Columbia, Canada) } \\
\text { [1251] compared to a sample } \\
\text { of non-Native children at each } \\
\text { site [457] }\end{array}$ & $\begin{array}{l}\text { DV: Depressive symptoms } \\
\text { using new measures of } \\
\text { psychopathology and mental } \\
\text { health (the SOS) }\end{array}$ & $\begin{array}{l}\text { 1. No explicit definition given for ethnicity. } \\
\text { 2. Study specifically interested in cultural } \\
\text { differences between the various First Nation } \\
\text { groups across North America. }\end{array}$ \\
\hline $\begin{array}{l}\text { 12. DeWit et al., } 1999 \\
\text { (Ontario, Canada) }^{40}\end{array}$ & $\begin{array}{l}\mathrm{N}=4531 \\
\mathrm{~A}=19+ \\
\mathrm{S}=\text { Native Ontario Community Survey and the } \\
\text { Mental Health Supplement of the Ontario } \\
\text { Health Survey. } \\
\mathrm{D}=\text { Cross-sectional (but age at onset } \\
\text { information used to look at incidence) } \\
\mathrm{DA}=\text { Descriptive and chi-square and survival } \\
\text { analyses } \\
\mathrm{T}=\text { Analytic }\end{array}$ & $\begin{array}{l}\text { Native Indian [876]; } \\
\text { Non-Natives [3655] }\end{array}$ & $\begin{array}{l}\text { DV: Alcohol drug use and } \\
\text { onset }\end{array}$ & $\begin{array}{l}\text { 1. No explicit definition given for ethnicity. } \\
\text { 2. Study specifically interested in cultural } \\
\text { differences between Native Indians and } \\
\text { non-Natives in Canada. }\end{array}$ \\
\hline $\begin{array}{l}\text { 13. DeWit and } \\
\text { Beneteau, } 1999 \\
\text { (Ontario, Canada) }^{41}\end{array}$ & $\begin{array}{l}N=5150 \\
A=16+ \\
S=1990 \text { Ontario Health Survey } \\
D=\text { Cross-sectional but age at onset } \\
\text { information allowed survival analyses } \\
D A=\text { Chi-square, survival and logistic } \\
\text { regression analyses } \\
T=\text { Analytic }\end{array}$ & $\begin{array}{l}\text { Anglophone [4023]; } \\
\text { Francophone [1127] }\end{array}$ & $\begin{array}{l}\text { DV: Alcohol consumption (i.e. } \\
\text { frequency and volume); } \\
\text { alcohol-related problems (i.e. } \\
\text { driving under the influence, } \\
\text { family conflicts, work conflicts, } \\
\text { sought help for drinking, } \\
\text { hospitalization for drinking, } \\
\text { and/or arrested for drunk } \\
\text { behaviour) }\end{array}$ & $\begin{array}{l}\text { 1. No explicit definition of ethnicity given. } \\
\text { 2. Ethnicity based on a combination of ethnic } \\
\text { identity and primary language used at } \\
\text { home. }\end{array}$ \\
\hline $\begin{array}{l}\text { 14. DeWit and } \\
\text { Beneteau, } 1999 \\
\text { (Ontario, Canada) }^{42}\end{array}$ & $\begin{array}{l}N=5150 \\
A=16+ \\
S=1990 \text { Ontario Health Survey } \\
D=\text { Cross-sectional but age at onset } \\
\text { information allowed survival analyses } \\
D A=\text { Chi-square, survival and logistic } \\
\text { regression analyses } \\
T=\text { Analytic }\end{array}$ & $\begin{array}{l}\text { Anglophone [4023]; } \\
\text { Francophone [1127] }\end{array}$ & $\begin{array}{l}\text { DV: Daily tobacco } \\
\text { consumption (i.e. frequency } \\
\text { and volume) }\end{array}$ & $\begin{array}{l}\text { 1. No explicit definition of ethnicity given. } \\
\text { 2. Ethnicity based on a combination of ethnic } \\
\text { identity and primary language used at } \\
\text { home. }\end{array}$ \\
\hline $\begin{array}{l}\text { 15. Feldman et al., } 1999 \\
\text { (Toronto, Ontario, }^{\text {Canada) }}{ }^{43}\end{array}$ & $\begin{array}{l}N=1236 \\
A=\text { Grade } 9 \text { to } 13 \text { students } \\
S=1994 \text { Survey of Grade } 9 \text { to } 13 \text { students in } \\
\text { the Borough of East York, Toronto } \\
D=\text { Cross-sectional } \\
D A=\text { descriptive analyses, stratified analyses } \\
\text { and multiple logistic regression analyses } \\
T=\text { Analytic }\end{array}$ & $\begin{array}{l}\text { Canadian [379]; } \\
\text { European [277]; } \\
\text { Asian [314]; } \\
\text { Other [140]; } \\
\text { Not stated [126] }\end{array}$ & $\begin{array}{l}\text { DV: Alcohol use beliefs and } \\
\text { behaviour }\end{array}$ & $\begin{array}{l}\text { 1. No definition given for ethnicity. } \\
\text { 2. "Please write down the term that best } \\
\text { describes the ethnic character of your } \\
\text { everyday home environment" was used to } \\
\text { ascertain ethnicity indicating an ethnic } \\
\text { identity conceptualization. }\end{array}$ \\
\hline
\end{tabular}




\begin{tabular}{|c|c|c|c|c|}
\hline $\begin{array}{l}\text { Author(s), year of } \\
\text { publication \& region } \\
\text { of study }\end{array}$ & $\begin{array}{c}\text { Study Sample } \\
\text { (sample size, data source, age } \\
\text { group included and study design) }\end{array}$ & Ethnic groups included & Outcome Examined & Comments \\
\hline $\begin{array}{l}\text { 16. Beiser et al., } 2000 \\
\text { (Canada \& US) }^{44}\end{array}$ & $\begin{array}{l}\mathrm{N}=2044 \\
\mathrm{~A}=7 \text { to } 9 \text { (Grades } 2 \text { and } 4 \text { ) } \\
\mathrm{S}=\text { Flower of Two Soils Project and the School } \\
\text { Option for Native Children Study } \\
\mathrm{D}=\text { Prospective and longitudinal } \\
\mathrm{DA}=\text { Principal component factor analysis on } \\
\text { the psychopathology measure, correlation } \\
\text { analyses, ANOVA, chi-square analyses } \\
\mathrm{T}=\text { Analytic }\end{array}$ & $\begin{array}{l}\text { First Nation children from the } \\
\text { Plains (South Dakota, US), } \\
\text { Northern Woodlands } \\
\text { (Manitoba, Canada), Desert } \\
\text { (New Mexico, US) and Coastal } \\
\text { (British Columbia, Canada) } \\
\text { [1555]; compared to a sample } \\
\text { non-Native children at each } \\
\text { site [489]. }\end{array}$ & $\begin{array}{l}\text { DV: Attention Deficit/ } \\
\text { Hyper-activity Disorder } \\
\text { (ADHD) per DSM symptom } \\
\text { criterion but items measured } \\
\text { by the TIF, the CAP and the } \\
\text { SOS scales which contained } \\
\text { items drawn from the CBCL, } \\
\text { the CPTRS and the DIS for } \\
\text { Children }\end{array}$ & $\begin{array}{l}\text { 1. No explicit definition given for ethnicity. } \\
\text { 2. Study specifically interested in cultural } \\
\text { differences between the various First Nation } \\
\text { groups across North America, hence it is } \\
\text { implied that ethnicity is based on culture. }\end{array}$ \\
\hline $\begin{array}{l}\text { 17. Lavallee \& Bourgault, } \\
2000 \text { (Canada) }^{45}\end{array}$ & $\begin{array}{l}N=27130 \text { women } \\
A=15+ \\
S=1991 \text { Cree Health Survey, } 1992 \text { Inuit Health } \\
\text { Survey \& 1992-93 Quebec Health and Social } \\
\text { Survey } \\
D=\text { Cross-sectional } \\
D A=\text { Weighted Frequency distribution, } \\
\text { Chi-square and ANOVA analyses } \\
T=\text { Descriptive }\end{array}$ & $\begin{array}{l}\text { Cree [1999]; } \\
\text { Inuit [1597]; } \\
\text { Southern Quebecers [23 564] }\end{array}$ & $\begin{array}{l}\text { DV: Alcohol consumption, } \\
\text { illicit drug use, psychological } \\
\text { distress, lifetime suicidal } \\
\text { thoughts }\end{array}$ & $\begin{array}{l}\text { 1. Researchers interested in the mental health } \\
\text { of Cree, Inuit and Southern Quebec women, } \\
\text { so no mention or definition of ethnicity. } \\
\text { 2. The group 'Southern Quebec' likely } \\
\text { included multiple ethnic groups. }\end{array}$ \\
\hline 18. Ali, 2002 (Canada) $)^{5}$ & $\begin{array}{l}N=92379 \\
A=15 \text { to } 75 \\
S=\text { Canadian Community Health Survey, Cycle } \\
1.1 \\
D=\text { Cross-sectional } \\
D A=\text { Multiple logistic regression analysis } \\
T=\text { Analytic }\end{array}$ & $\begin{array}{l}\text { US/Mexico [952]; S. America, } \\
\text { C. America, Caribbean [2273]; } \\
\text { Europe [7749]; Africa [1139]; } \\
\text { Asia [6314] }\end{array}$ & $\begin{array}{l}\text { DV: Depression \& alcohol } \\
\text { dependence }\end{array}$ & $\begin{array}{l}\text { 1. Ethnic origin based on region of birth. } \\
\text { 2. Although immigrants broken down into } \\
\text { regions migrated from, the Canadian-born } \\
\text { group wasn't, which limited comparisons } \\
\text { based on ethnicity. }\end{array}$ \\
\hline $\begin{array}{l}\text { 19. Beiser et al., } 2002 \\
{\text { (Canada) }{ }^{46}}\end{array}$ & $\begin{array}{l}N=13349 \\
A=4 \text { to } 11 \\
S=\text { National Longitudinal Survey of Children \& } \\
\text { Youth (NLSCY/1994-1995) } \\
D=\text { Cross-sectional } \\
D A=\text { Multiple logistic regression analyses } \\
T=\text { Analytic }\end{array}$ & $\begin{array}{l}\text { Immigrants [684]; Born in } \\
\text { Canada to immigrant parents } \\
\text { [2573]; Canadian-born to } \\
\text { Canadian-born parents [10 } \\
\text { 092]. } \\
\text { Ethnicity then examined } \\
\text { (Asian, Black, other, White/ } \\
\text { European). }\end{array}$ & $\begin{array}{l}\text { DV: Emotional and } \\
\text { behavioural problems }\end{array}$ & $\begin{array}{l}\text { 1. Ethnicity examined as a covariate. } \\
\text { 2. Ethnic origin based on ethnicity question. } \\
\text { 3. The "Others" race/ethnicity category not } \\
\text { clearly defined. }\end{array}$ \\
\hline 20. Ma, 2002 (Canada) $)^{47}$ & $\begin{array}{l}N=2304 \\
A=7 \text { to } 11 \\
S=\text { NLSCY } 1994 / 5 \\
D=\text { Cross-sectional } \\
D A=\text { Factor analysis and mixed level modeling } \\
T=\text { Analytic }\end{array}$ & $\begin{array}{l}\text { Immigrant Children [182]; } \\
\text { Non-immigrant Children } \\
\text { [2122]. Ethnicity then } \\
\text { examined as a covariate (US, } \\
\text { Europe, Asia, other regions). }\end{array}$ & $\begin{array}{l}\text { DV: Conduct disorder, indirect } \\
\text { aggression, property offences, } \\
\text { hyperactive behaviour, } \\
\text { pro-social disorder, emotional } \\
\text { disorder \& a composite } \\
\text { behavioural /emotional } \\
\text { disorder index }\end{array}$ & $\begin{array}{l}\text { 1. Ethnic origin based on region of birth. } \\
\text { 2. Ethnicity examined as a covariate. } \\
\text { 3. No definition given for ethnicity. }\end{array}$ \\
\hline $\begin{array}{l}\text { 21. Mata, } 2002 \\
\text { (Canada) }^{48}\end{array}$ & $\begin{array}{l}N=17109 \\
A=15+ \\
S=\text { National Survey of Giving, Volunteering and } \\
\text { Participating } \\
D=\text { Cross-sectional } \\
D A=\text { Multiple regression analyses } \\
T=\text { Analytic }\end{array}$ & $\begin{array}{l}19 \text { Single/multiple ethnic } \\
\text { categories (Canadian, French, } \\
\text { British, German, Ukranian, } \\
\text { Polish, Italian/Portuguese, } \\
\text { Dutch, Chinese, Black/South } \\
\text { Asian, Aboriginal, Canadian \& } \\
\text { French, Canadian \& British, } \\
\text { Canadian \& Other, British \& } \\
\text { French, French \& Other, } \\
\text { European, Rest of singles, Rest } \\
\text { of multiples) }\end{array}$ & $\begin{array}{l}\text { DV: Life satisfaction (4-pt } \\
\text { Likert scale) }\end{array}$ & $\begin{array}{l}\text { 1. Ethnic origin based on the ethnicity } \\
\text { question in the survey. } \\
\text { 2. Mutually exclusive ethnic groupings driven } \\
\text { in part by sample size issues. } \\
\text { 3. Rationale for some ethnic groupings } \\
\text { unclear. } \\
\text { 4. No definition of ethnicity. }\end{array}$ \\
\hline 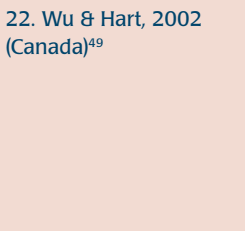 & $\begin{array}{l}N=3009 \text { elderly immigrants } \\
A=65+ \\
S=\text { National Population Health Survey (NPHS, } \\
1996 \text { ) } \\
D=\text { Cross-sectional component } \\
D A=\text { Descriptive and multiple linear regression } \\
\text { analyses } \\
T=\text { Analytic }\end{array}$ & $\begin{array}{l}\text { Chinese/South Asian [274]; } \\
\text { Other [2735] }\end{array}$ & $\begin{array}{l}\text { DV: Emotional problems and } \\
\text { psychological distress (CIDI) }\end{array}$ & $\begin{array}{l}\text { 1. Ethnicity based on the ethnic origin } \\
\text { question in the survey. } \\
\text { 2. The combination of Chinese and all South } \\
\text { Asians indicate that ethnic origin based on } \\
\text { large geo-cultural region. }\end{array}$ \\
\hline $\begin{array}{l}\text { 23. Wu et al., } 2003 \\
\text { (Canada) }^{2}\end{array}$ & $\begin{array}{l}\mathrm{N}=70538 \\
\mathrm{~A}=12+ \\
\mathrm{S}=\mathrm{NPHS}, 1996 \\
\mathrm{D}=\text { Cross-sectional component } \\
\text { DA: Descriptive and multiple linear regression } \\
\text { analyses } \\
\mathrm{T}=\text { Analytic }\end{array}$ & $\begin{array}{l}\text { East \& Southeast Asian [624]; } \\
\text { Chinese [800]; South Asian } \\
\text { [809]; Aboriginal [975]; } \\
\text { Black [788]; Arabic \& West } \\
\text { Asian [325]; Latin American } \\
\text { [176]; Jewish [197]; French } \\
\text { [5580]; } \\
\text { English [9281]; “Other” Whites } \\
\text { [50 294]; Mixed race [689] }\end{array}$ & DV: Depression (CIDI) & $\begin{array}{l}\text { 1. Ethnicity based on the ethnic origin } \\
\text { question in the survey and in combination } \\
\text { with race used to create ethno-racial } \\
\text { groups. } \\
\text { 2. Offered definitions of race and ethnicity a } \\
\text { priori. }\end{array}$ \\
\hline
\end{tabular}




\begin{tabular}{|c|c|c|c|c|}
\hline $\begin{array}{l}\text { Author(s), year of } \\
\text { publication \& region } \\
\text { of study }\end{array}$ & $\begin{array}{c}\text { Study Sample } \\
\text { (sample size, data source, age } \\
\text { group included and study design) }\end{array}$ & Ethnic groups included & Outcome Examined & Comments \\
\hline $\begin{array}{l}\text { 24. Blackstock et al., } \\
2004 \text { (Canada) }^{50}\end{array}$ & $\begin{array}{l}N=3159 \\
A=\text { childhood (range not given) } \\
S=1998 \text { Canadian Incidence Study of Reported } \\
\text { Child Abuse and Neglect (CIS-98) } \\
D=\text { Cross-sectional } \\
D A=\text { Chi-square and ANOVA analyses } \\
T=\text { Descriptive }\end{array}$ & $\begin{array}{l}\text { Aboriginal [614]; } \\
\text { White [2114]; } \\
\text { Other Visible Minority [431] }\end{array}$ & $\begin{array}{l}\text { DV: Frequency of Child } \\
\text { Maltreatment (physical and } \\
\text { sexual abuse and neglect); } \\
\text { psychosocial problems }\end{array}$ & $\begin{array}{l}\text { 1. No explicit definition of ethnicity given. } \\
\text { 2. Ethno-racial classification determined by } \\
\text { ethno-racial status of one or both biological } \\
\text { parents. } \\
\text { 3. Conceptualized based on ethnic origin. }\end{array}$ \\
\hline $\begin{array}{l}\text { 25. Cohen \& Maclean, } \\
2004 \text { (Canada) }^{51}\end{array}$ & $\begin{array}{l}N=26000 \\
A=15+ \\
S=\text { All females from the } 1999 \text { General Social } \\
\text { Survey } \\
D=\text { Cross-sectional } \\
D A=\text {-test with } p<0.05 \text { significance level } \\
T=\text { Descriptive }\end{array}$ & $\begin{array}{l}\text { Visible minority vs. non-visible } \\
\text { minority; } \\
\text { Aboriginal vs. non-Aboriginal }\end{array}$ & $\begin{array}{l}\text { DV: Physical, sexual, financial } \\
\text { or emotional abuse; } \\
\text { medication use for anxiety, } \\
\text { depression or insomnia in } \\
\text { those abused. }\end{array}$ & $\begin{array}{l}\text { 1. Ethnicity based on country of birth. } \\
\text { 2. No definition given for visible minority. }\end{array}$ \\
\hline $\begin{array}{l}\text { 26. Wang \& El-Guebaly, } \\
2004 \text { (Canada) }^{52}\end{array}$ & $\begin{array}{l}N=72940 \\
A=12+ \\
S=\text { NPHS (1996/7) } \\
D=\text { Cross-sectional } \\
\text { DA = Multiple logistic regression analyses } \\
T=\text { Analytic }\end{array}$ & $\begin{array}{l}\text { White [67 802]; } \\
\text { Non-White [5138] }\end{array}$ & $\begin{array}{l}\text { DV: Major depressive episode } \\
\text { (MDE), alcohol dependence } \\
\text { (AD) and mental health } \\
\text { service use }\end{array}$ & $\begin{array}{l}\text { 1. Ethnicity examined as a covariate. } \\
\text { 2. No description of the groups included in the } \\
\text { non-white category. } \\
\text { 3. Non-white population likely included } \\
\text { Aboriginals, a group with great likelihood } \\
\text { of MDE and AD, which likely explains the } \\
\text { higher risk observed in non-immigrant } \\
\text { non-whites. } \\
\text { 4. Race only categorization despite use of the } \\
\text { term "ethnicity". }\end{array}$ \\
\hline $\begin{array}{l}\text { 27. Rousseau \& } \\
\text { Drapeau, } 2004 \\
\text { (Montreal, Quebec, }^{5} \\
\text { Canada) }^{53}\end{array}$ & $\begin{array}{l}\mathrm{N}=1871 \\
\mathrm{~A}=15 \text { to } 87 \\
\mathrm{~S}=\text { Quebec Cultural Communities Survey } \\
\text { (survey of recent immigrants living in the } \\
\text { metropolitan Montreal area who landed in } \\
\text { Canada between } 1988 \text { and 1997) } \\
\mathrm{D}=\text { Cross-sectional } \\
\mathrm{DA}=\text { Chi-square, } \mathrm{t} \text {-test, ANOVA } \\
\mathrm{T}=\text { Descriptive }\end{array}$ & $\begin{array}{l}\text { Chinese; } \\
\text { Arab; } \\
\text { Haitian; } \\
\text { Hispanics } \\
\text { Note: indicated in the article } \\
\text { that equal numbers of each } \\
\text { ethnic group were selected } \\
\text { from the registry to represent } \\
\text { the target population [n }=750 \\
\left.{ }^{*} 4=3000\right] \text { but the eligible } \\
\text { population was } 1871 \text { with no } \\
\text { breakdown of the numbers in } \\
\text { each ethnic group }\end{array}$ & $\begin{array}{l}\text { DV: Emotional distress (i.e. } \\
\text { depression and anxiety) per } \\
\text { the SCL-25 based on the } \\
\text { Hopkins Symptom Checklist }\end{array}$ & $\begin{array}{l}\text { 1. Explicit definition of ethnicity not given. } \\
\text { 2. Researchers interested in recent immigrants } \\
\text { in the Montreal area who were born in one } \\
\text { of four geocultural areas (China, Hong } \\
\text { Kong, Taiwan and Macao [Chinese], Haiti } \\
\text { [Haitian], North Africa and the Middle East } \\
\text { [Arabs] and Latin America [Hispanics]. } \\
\text { Therefore, ethnicity conceptualized based } \\
\text { on region of birth. }\end{array}$ \\
\hline \multicolumn{5}{|c|}{ Smaller studies with primary data collection - non-clinical sample $(\mathbf{n}=12)$} \\
\hline $\begin{array}{l}\text { 28. Fry \& Grover, } 1982 \\
\text { (Canada \& USA) }\end{array}$ & $\begin{array}{l}\mathrm{N}=320 \\
\mathrm{~A}=65 \text { to } 80 \\
\mathrm{~S}=\text { Random sample drawn form professional } \\
\text { clubs, community associations, recreation } \\
\text { centres for elderly, social welfare agencies and } \\
\text { private homes. } \\
\mathrm{D}=\text { Cross-sectional } \\
\mathrm{DA}=\text { ANOVA } \\
\mathrm{T}=\text { Analytic }\end{array}$ & $\begin{array}{l}\text { Asian-Indian [160]; Caucasian } \\
\text { [160] }\end{array}$ & $\begin{array}{l}\text { DV: Depression (per the BDI), } \\
\text { life stress [per the Life Event } \\
\text { Inventory], cognitive appraisal } \\
\text { and locus of control }\end{array}$ & $\begin{array}{l}\text { 1. Definition of ethnicity not given. } \\
\text { 2. How ethnicity ascertained unclear. } \\
\text { 3. Seem to be a race only categorization. }\end{array}$ \\
\hline 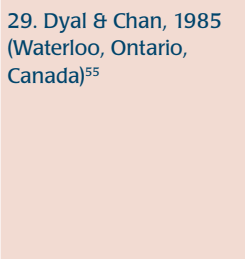 & $\begin{array}{l}\mathrm{N}=251 \\
\mathrm{~A}=17 \text { to } 29 \\
\mathrm{~S}=\text { Samples of convenience (i.e. students in } \\
\text { undergraduate courses and some volunteers) } \\
\mathrm{D}=\text { Cross-sectional } \\
\mathrm{DA}=\text { ANOVA and ANCOVA } \\
\mathrm{T}=\text { Analytic }\end{array}$ & $\begin{array}{l}\text { Euro-Canadian [112]; } \\
\text { Hong Kong Chinese [100]; } \\
\text { Chinese immigrants to } \\
\text { Canada [39] }\end{array}$ & $\begin{array}{l}\text { DV: Stressful life events per } \\
\text { the Problems with Living } \\
\text { Adjustment scale (developed } \\
\text { for the study); distress per the } \\
\text { DSS based on Langer } 22 \text {-item } \\
\text { scale of impaired functioning; } \\
\text { 12- items from the DDS; worry } \\
\text { per the worry scale of the } \\
\text { SEAS. }\end{array}$ & $\begin{array}{l}\text { 1. No explicit definition given for ethnicity. } \\
\text { 2. Implication that ethnicity based on culture } \\
\text { since the study interested in cross-cultural } \\
\text { differences. } \\
\text { 3. Unclear whether the Euro-Canadian groups } \\
\text { actually identified themselves as such or if } \\
\text { this categorization based on the } \\
\text { researchers' observations. }\end{array}$ \\
\hline $\begin{array}{l}\text { 30. Blandford \& } \\
\text { Chappell, } 1990 \\
\text { (Winnipeg, Manitoba, }^{\text {Canada) }}{ }^{56}\end{array}$ & $\begin{array}{l}N=390 \\
A=50 \text { and over } \\
S=\text { Survey of Natives in Winnipeg in } 1981 \\
D=\text { Cross-sectional } \\
D A=\text { Chi-square and logistic regression } \\
\text { analyses } \\
T=\text { Analytic }\end{array}$ & $\begin{array}{l}\text { Natives [193] } \\
\text { Non-Natives [197] }\end{array}$ & $\begin{array}{l}\text { DV: Satisfaction with life; } \\
\text { loneliness per the UCLA } \\
\text { Loneliness Scale }\end{array}$ & $\begin{array}{l}\text { 1. Ethnicity not specifically defined. } \\
\text { 2. Conceptualized based on ethnic identity but } \\
\text { no indication of how ethnic identity was } \\
\text { ascertained. }\end{array}$ \\
\hline $\begin{array}{l}\text { 31. Dion \& Giordano, } \\
1990 \text { (Toronto, Ontario, } \\
\text { Canada) }^{57}\end{array}$ & $\begin{array}{l}\mathrm{N}=352 \\
\mathrm{~A}=1 \text { st-year university students - mean age of } \\
20.32 \text { years (1988) } \\
\mathrm{S}=\mathrm{A} \text { sample of undergraduate students in an } \\
\text { introductory psychology course } \\
\mathrm{D}=\text { Cross-sectional } \\
\mathrm{DA}=\text { ANOVA, } \mathrm{X}^{2} \text {, and multivariate log-linear } \\
\text { analyses } \\
\mathrm{T}=\text { Analytic }\end{array}$ & $\begin{array}{l}\text { Anglo-Celtic [165]; North } \\
\text { European [22]; } \\
\text { South European [79]; East } \\
\text { European [36]; } \\
\text { East Asians [25]; } \\
\text { South Asians [25] } \\
\text { IV: Sex and ethnicity }\end{array}$ & $\begin{array}{l}\text { DV: Depression (total \& item } \\
\text { scores for the BDI) }\end{array}$ & $\begin{array}{l}\text { 1. Ethnic origin based on surnames, with the } \\
\text { aid of a number of dictionaries of } \\
\text { surnames/family names. } \\
\text { 2. This limited the ability to identify black } \\
\text { individuals with West Indian ethno-cultural } \\
\text { background and South Asians of Christian } \\
\text { background. }\end{array}$ \\
\hline
\end{tabular}




\begin{tabular}{|c|c|c|c|c|}
\hline $\begin{array}{l}\text { Author(s), year of } \\
\text { publication \& region } \\
\text { of study }\end{array}$ & $\begin{array}{c}\text { Study Sample } \\
\text { (sample size, data source, age } \\
\text { group included and study design) }\end{array}$ & Ethnic groups included & Outcome Examined & Comments \\
\hline $\begin{array}{l}\text { 32. Bagley, } 1993 \\
\text { (Calgary, Alberta, } \\
\text { Canada \& Kowloop, } \\
\text { Hong Kong, China) }^{58}\end{array}$ & $\begin{array}{l}\mathrm{N}=300 \\
\mathrm{~A}=60 \text { to } 74 \text { years old } \\
\mathrm{S}=\text { The } 100 \text { Canadian-dwelling elderly } \\
\text { Cantonese-speaking Chinese sample was } \\
\text { recruited by randomly selecting Chinese } \\
\text { surnames from the telephone directory with an } \\
\text { initial call by a Cantonese-speaking individual } \\
\text { who established the presence of an elderly } \\
\text { person (aged } 60 \text { to } 74 \text { ) and then inquired about } \\
\text { and established the ethnic origin of the } \\
\text { individual. Stratified sampling of young to } \\
\text { elderly in Kowloop, Hong Kong to match the } \\
\text { age and sex profile of Canadian-dwelling } \\
\text { Cantonese-speaking elderly Chinese group. } \\
\mathrm{D}=\text { Cross-sectional } \\
\mathrm{DA}=\text { Comparison of the standardized scores } \\
\mathrm{T}=\text { Descriptive }\end{array}$ & $\begin{array}{l}\text { Canadian born of European } \\
\text { descent [100]; } \\
\text { Chinese immigrants long } \\
\text { established in Canada [50]; } \\
\text { Chinese immigrants newly } \\
\text { arrived in Canada [50]; } \\
\text { Chinese in Hong Kong [100] }\end{array}$ & $\begin{array}{l}\text { DV: Physical and mental } \\
\text { health as measured by the } \\
\text { GHQ; loneliness per the UCLA } \\
\text { Loneliness Scale; quality of } \\
\text { life \& acculturation; \& global } \\
\text { satisfaction with life }\end{array}$ & $\begin{array}{l}\text { 1. Explicit definition given for ethnicity. } \\
\text { 2. Different techniques seem to have been } \\
\text { used to establish ethnicity across groups. } \\
\text { Surnames, language and unknown question } \\
\text { for Canadian dwelling Chinese; country of } \\
\text { birth for Hong Kong Chinese and unknown } \\
\text { method for Euro-Canadians. }\end{array}$ \\
\hline $\begin{array}{l}\text { 33. Dion, } 1996 \text { (Toronto, } \\
\text { Canada) }^{59}\end{array}$ & $\begin{array}{l}N=950 \\
A=\text { ?18- } 21: 1^{\text {st }} \text {-year university students } \\
S=\text { Convenience sample } \\
D=\text { Cross-sectional } \\
D A=\text { ANOVA } \\
T=\text { Exploratory }\end{array}$ & $\begin{array}{l}\text { Language as indicator of } \\
\text { ethnic origin } \\
\text { English; } \\
\text { Chinese; } \\
\text { European }\end{array}$ & $\begin{array}{l}\text { DV: Alexithymia (TAS-20) and } \\
\text { three under-lying factors } \\
\text { (DIF= difficulty identifying } \\
\text { feelings, DDF= difficulty } \\
\text { describing feelings, EOT= } \\
\text { externally oriented thinking) }\end{array}$ & $\begin{array}{l}\text { 1. Language identified by Dion as a possible } \\
\text { proxy of ethnicity (i.e. ethnic origin). } \\
\text { 2. No definition for ethnicity. }\end{array}$ \\
\hline $\begin{array}{l}\text { 34. Heine and Lehman, } \\
1999 \text { (Canada \& } \\
\text { Japan) }{ }^{60}\end{array}$ & $\begin{array}{l}N=402 \\
A=18 \text { to } 25 ? \\
S=\text { Survey of university students } \\
D=\text { Cross-sectional } \\
D A=\text { ANOVA with post hoc tests (Tukey's HSD) } \\
T=\text { Analytic }\end{array}$ & $\begin{array}{l}\text { Japanese [161]; } \\
\text { Asian-Canadian [151]; } \\
\text { Euro-Canadian [90] }\end{array}$ & $\begin{array}{l}\text { DV: Personality traits: } 20 \\
\text { items to capture the } \\
\text { individuals' ratings of their } \\
\text { actual \& ideal self and what } \\
\text { they thought described the } \\
\text { average student traits; } \\
\text { difference between actual \& } \\
\text { ideal self, and importance of } \\
\text { traits to success in one's } \\
\text { country were also assessed; } \\
\text { depression (ZSDS) }\end{array}$ & $\begin{array}{l}\text { 1. No explicit definition given for ethnicity; it } \\
\text { appeared to be based on culture. } \\
\text { 2. Method of sample selection unclear. } \\
\text { 3. SES and/or SS hypotheses not tested. }\end{array}$ \\
\hline $\begin{array}{l}\text { 35. Rousseau et al., } \\
2001 \text { (Montréal, } \\
\text { Canada) }^{61}\end{array}$ & $\begin{array}{l}N=113 \\
A=20 \text { to } 65 \\
S=\text { Sample of refugees who sought help from } \\
\text { community organizations that provide services } \\
\text { to refugees/immigrants in the Montreal area } \\
D=\text { Qualitative \& cross-sectional quantitative } \\
\text { design combined } \\
D A=\text { Descriptive analyses and Spearman rank } \\
\text { correlation and t-tests for comparative analyses } \\
T=\text { Descriptive }\end{array}$ & $\begin{array}{l}\text { Latin American [60]; } \\
\text { African American [53] }\end{array}$ & $\begin{array}{l}\text { DV: Emotional profile of } \\
\text { subjects based on the } \\
\text { SCL-90R; Post-traumatic stress } \\
\text { disorder per the DSM-IV. }\end{array}$ & $\begin{array}{l}\text { 1. Ethnic origin based on geo-cultural region } \\
\text { of birth. } \\
\text { 2. Explicit definition of ethnicity not given. }\end{array}$ \\
\hline $\begin{array}{l}\text { 36. Howard et al, } 2003 \\
\text { (Toronto, Ontario, } \\
\text { Canada; USA; Taipei } \\
\text { City, Taiwan) }\end{array}$ & $\begin{array}{l}\mathrm{N}=3030 \\
\mathrm{~A}=\text { not given } \\
\mathrm{S}=\text { All participants from Canada are volunteers } \\
\text { recruited through newspaper and flyer } \\
\text { advertisements in Toronto; Taiwanese recruited } \\
\text { at the Taipei City Psychiatric Center; African } \\
\text { American smokers recruited at the University of } \\
\text { Kansas Medical Center (Clinical and community } \\
\text { settings) } \\
\mathrm{D}=\text { Association Analysis (Cross-sectional) } \\
\mathrm{DA}=\text { ANOVA; T-test, Mann-Whitney U-test and } \\
\text { Chi-square analyses } \\
\mathrm{T}=\text { Analytic }\end{array}$ & $\begin{array}{l}\text { From Canada: } \\
\text { Indo-Asian [48]; } \\
\text { Chinese [210]; } \\
\text { Japanese [128]; } \\
\text { African Canadian [58]; } \\
\text { Native Indian [228]; } \\
\text { Caucasian [1734] } \\
\text { Elsewhere: } \\
\text { Taiwanese [420]; } \\
\text { African American [204] }\end{array}$ & $\begin{array}{l}\text { DV: CYP2E1*1D allele; alcohol } \\
\text { inactivation }\end{array}$ & $\begin{array}{l}\text { 1. Ethnicity not explicitly defined. } \\
\text { 2. Ethnic background based on the } \\
\text { individual's grandparents therefore an } \\
\text { ethnic origin conceptualization. }\end{array}$ \\
\hline $\begin{array}{l}\text { 37. Tweed et al., } 2004 \\
\text { (British Columbia, } \\
\text { Canada and Japan) }^{63}\end{array}$ & $\begin{array}{l}\mathrm{N}=123 \text { (Study } 1 \text { ) } \\
415 \text { (Study } 2 \text { ) } \\
\mathrm{A}=18 \text { to } 47 \\
\mathrm{~S}=\text { Undergraduate students from the University } \\
\text { of British Columbia, Canada and from } \\
\text { Ritsumeikan University (Study } 1 \text { ) or Kurume } \\
\text { University (Study } 2 \text { ), Japan } \\
\mathrm{D}=\text { Cross-sectional } \\
\mathrm{DA}=\text { MANCOVA } \\
\mathrm{T}=\text { Analytic }\end{array}$ & $\begin{array}{l}\text { Study 1: } \\
\text { Western European Canadian } \\
\text { [22]; } \\
\text { East Asian Canadian [57]; } \\
\text { South Asian/Mixed descent } \\
\text { Canadian [18]; } \\
\text { Japanese [26] } \\
\text { Study 2: } \\
\text { European Canadian [68]; } \\
\text { East-Asian Canadian [106]; } \\
\text { Japanese [241] }\end{array}$ & $\begin{array}{l}\text { DV: Stressful and negative life } \\
\text { events; coping skills per the } \\
\text { WCCL and Japanese coping } \\
\text { items }\end{array}$ & $\begin{array}{l}\text { 1. Ethnicity not explicitly defined but based on } \\
\text { culture. } \\
\text { 2. Conceptualized based on descent, therefore } \\
\text { ethnic origin. }\end{array}$ \\
\hline
\end{tabular}




\begin{tabular}{|c|c|c|c|c|}
\hline $\begin{array}{l}\text { Author(s), year of } \\
\text { publication \& region } \\
\text { of study }\end{array}$ & $\begin{array}{c}\text { Study Sample } \\
\text { (sample size, data source, age } \\
\text { group included and study design) }\end{array}$ & Ethnic groups included & Outcome Examined & Comments \\
\hline $\begin{array}{l}\text { 38. Khanlou, } 2004 \\
\text { (Hamilton, Ontario, } \\
\text { Canada) }^{64}\end{array}$ & $\begin{array}{l}N=550 \\
A=\text { Grades } 9 \text { to } 13 \\
S=\text { Survey of students at } 4 \text { secondary schools } \\
\text { in the Hamilton Wentworth region in } 1998 \\
D=\text { Cross-sectional } \\
D A=\text { Chi-square and ANOVA analyses } \\
T=\text { Descriptive }\end{array}$ & $\begin{array}{l}\text { Information given for the } \\
\text { three most frequently } \\
\text { occurring ethnic/cultural } \\
\text { background of the mothers } \\
\text { and fathers of the students. } \\
\text { Based on mother: } \\
\text { Italian [48]; } \\
\text { Portuguese [43]; } \\
\text { Irish [35]; } \\
\text { English [35] } \\
\text { Based on Father: } \\
\text { Italian [69]; } \\
\text { Portuguese [42]; } \\
\text { Canadian [38] }\end{array}$ & $\begin{array}{l}\text { DV: Self-esteem per the RSE } \\
\text { and the CSE scales }\end{array}$ & $\begin{array}{l}\text { 1. No definition given for ethnicity. } \\
\text { 2. Ethnicity based on the "parents' original } \\
\text { ethnic or cultural background" indicating an } \\
\text { ethnic origin conceptualization. } \\
\text { 3. Specific ethnic groupings were used with } \\
\text { some having very small sample size. As a } \\
\text { result comparison only done on the top } \\
\text { three ethnic categorizations. } \\
\text { 4. The study indicated that close to } 30 \% \text { of } \\
\text { the sample reported } 2 \text { or more ethnic } \\
\text { backgrounds indicating a "mixed" ethnic } \\
\text { group. }\end{array}$ \\
\hline $\begin{array}{l}\text { 39. Aubert et al., } 2004 \\
\text { (Canada) }^{65}\end{array}$ & $\begin{array}{l}N=170 \\
A=18+ \\
S=\text { Convenience sample of students } \\
D=\text { Cross-sectional } \\
D A=\text { ANOVA } \\
T=\text { Analytic }\end{array}$ & $\begin{array}{l}\text { Other Canadian [81]; Chinese } \\
\text { Canadian [89] }\end{array}$ & $\begin{array}{l}\text { DV: Hostility (HDHQ); suicide } \\
\text { probability (SPS); lifetime } \\
\text { aggressive behaviour incl. } \\
\text { suicide attempt; suicidal } \\
\text { thoughts and deliberate self } \\
\text { harm }\end{array}$ & $\begin{array}{l}\text { 1. Ethnicity examined as a covariate } \\
\text { 2. It is unclear if "Other Canadian" group } \\
\text { include ethnicity other than } \\
\text { Anglo-Canadians. } \\
\text { 3. Ethnic origin based on country of birth. }\end{array}$ \\
\hline \multicolumn{5}{|c|}{ Smaller studies with primary data collection - clinical/specialized sample $(\mathbf{n}=10)$} \\
\hline $\begin{array}{l}\text { 40. Bland \& Orn, } 1981 \\
\text { (Alberta, Canada) }^{66}\end{array}$ & $\begin{array}{l}N=43 \text { (33 non-immigrants \& } 10 \text { immigrants) } \\
A=15 \text { to } 49 \\
S=1963 \text { First episode hospitalization data } \\
D=\text { Retrospective follow-up on a cohort of } \\
\text { persons with schizophrenia compared to the } \\
\text { general population } \\
D A=\text { Descriptive and Chi-square analyses } \\
T=\text { Descriptive }\end{array}$ & $\begin{array}{l}10 \text { immigrants classified as } \\
\text { "other European" [6], \& } \\
\text { Eastern European [4] }\end{array}$ & DV: Schizophrenia & $\begin{array}{l}\text { 1. Ethnicity examined as a covariate. } \\
\text { 2. The term "ethnic group" used but no } \\
\text { definition of what it means. } \\
\text { 3. Ethnic origin based on place of birth. }\end{array}$ \\
\hline $\begin{array}{l}\text { 41. Seltzer \& Langford, } \\
1984 \text { (Northwest }^{\text {Territories, Canada) }}{ }^{67}\end{array}$ & $\begin{array}{l}\mathrm{N}=85 \\
\mathrm{~A}=15 \text { to } 25 \\
\mathrm{~S}=\text { Sample of convenience (i.e. all persons } \\
\text { referred by the courts or legal counsel to the } \\
\text { Department of Psychiatry at the regional } \\
\text { hospital in the calendar year 1981) } \\
\mathrm{D}=\text { Cross-sectional } \\
\mathrm{DA}=\text { Descriptive } \\
\mathrm{T}=\text { Descriptive }\end{array}$ & $\begin{array}{l}\text { Inuit [41]; } \\
\text { Métis/Dene [27]; } \\
\text { Caucasian [17] }\end{array}$ & $\begin{array}{l}\text { DV: DSM-III psychiatric } \\
\text { diagnosis and type of criminal } \\
\text { offences committed }\end{array}$ & $\begin{array}{l}\text { 1. No explicit definition given for ethnicity. } \\
\text { 2. The Native group broken down into Inuit } \\
\text { and Metis, indicating cultural distinctions, } \\
\text { but the Caucasian group not disaggregated. }\end{array}$ \\
\hline $\begin{array}{l}\text { 42. Borzecki et al., } 1988 \\
\text { (Saskatoon, } \\
\text { Saskatchewan, } \\
\text { Canada) }^{68}\end{array}$ & $\begin{array}{l}\mathrm{N}=275 \text { (all males) } \\
\mathrm{A}=28.41=\text { mean age at admission } \\
\mathrm{S}=\text { successive } 1^{\text {st }} \text { admission to the facility } \\
\text { between January } 1978 \text { and September } 1982 \\
\mathrm{D}=\text { Cross-sectional } \\
\mathrm{DA}=\text { ANOVA, ANCOVA, and Pearson's } \\
\text { correlation } \\
\mathrm{T}=\text { Analytic }\end{array}$ & $\begin{array}{l}\text { Natives (i.e. Inuit, Métis, and } \\
\text { Indians) [57]; } \\
\text { Non-Natives [218] }\end{array}$ & $\begin{array}{l}\text { DV: Psychological profile per } \\
\text { the MMPI }\end{array}$ & $\begin{array}{l}\text { 1. No explicit definition of ethnicity given. } \\
\text { 2. Ethnicity based on ancestry (ethnic origin), at } \\
\text { least for the native sample, while all } \\
\text { non-natives, despite ancestral heterogeneity } \\
\text { are grouped together. }\end{array}$ \\
\hline $\begin{array}{l}\text { 43. Chandrasena et al., } \\
1991 \text { (Ontario, } \\
\text { Canada) }^{69}\end{array}$ & $\begin{array}{l}\mathrm{N}=117 \\
\mathrm{~A}=\text { range not given } \\
\mathrm{S}=\text { All suicides in } 3 \text { psychiatric facilities in } \\
\text { Ontario between } 1967 \text { and } 1990 \\
\mathrm{D}=\text { Cross-sectional } \\
\mathrm{DA}=\text { Descriptive Analyses } \\
\mathrm{T}=\text { Descriptive }\end{array}$ & $\begin{array}{l}\text { Canadian-born [94]; } \\
\text { Foreign-born [23] }\end{array}$ & DV: Suicide & $\begin{array}{l}\text { 1. Ethnicity mentioned but not defined. } \\
\text { 2. Canadian-born versus foreign-born indicate } \\
\text { a country of birth conceptualization but not } \\
\text { explicitly stated. }\end{array}$ \\
\hline $\begin{array}{l}\text { 44. Norton et al., } 1995 \\
\text { (Manitoba, Canada) }^{70}\end{array}$ & $\begin{array}{l}\mathrm{N}=80 \\
\mathrm{~A}=\text { ? } \\
\mathrm{S}=\text { Attendees at the Alcoholism Foundation of } \\
\text { Manitoba } \\
\mathrm{D}=\text { Cross-sectional } \\
\mathrm{DA}=\text { Chi-square } \\
\mathrm{T}=\text { Descriptive }\end{array}$ & $\begin{array}{l}\text { Native-Canadians [37]; } \\
\text { Anglo-Canadians [43] }\end{array}$ & $\begin{array}{l}\text { DV: Suicidal ideation (per } \\
\text { NIMH Epidemiologic } \\
\text { Catchment Area survey), panic } \\
\text { (PAQ), chemical abuse (the } \\
\text { BMAST \& DAST) and } \\
\text { depression (BDI) }\end{array}$ & $\begin{array}{l}\text { 1. No explicit definition of ethnicity given. } \\
\text { 2. Unclear how ethnicity was ascertained. }\end{array}$ \\
\hline $\begin{array}{l}\text { 45. Weekes et al., } 1995 \\
\text { (Ontario, Canada) }^{71}\end{array}$ & $\begin{array}{l}\mathrm{N}=301 \\
\mathrm{~A}=18 \text { to } 59 \\
\mathrm{~S}=\text { Sample of convenience: Adult males } \\
\text { incarcerated in a medium security federal } \\
\text { prison } \\
\mathrm{D}=\text { Cross-sectional } \\
\mathrm{DA}=\text { MANOVA, T-TEST, correlation and } \\
\text { principal component analyses } \\
\mathrm{T}=\text { Analytic }\end{array}$ & $\begin{array}{l}\text { Caucasian [203]; } \\
\text { Native [59]; } \\
\text { Métis [39] }\end{array}$ & $\begin{array}{l}\text { DV: Psychopathology per the } \\
\text { MCMI }\end{array}$ & $\begin{array}{l}\text { 1. No explicit definition of ethnicity } \\
\text { 2. The terms ethnicity, "cultural group", and } \\
\text { "racial identification" used in the article but } \\
\text { categorization based on the individuals } \\
\text { self-report of "racial identification". }\end{array}$ \\
\hline
\end{tabular}




\begin{tabular}{|c|c|c|c|c|}
\hline $\begin{array}{l}\text { Author(s), year of } \\
\text { publication \& region } \\
\text { of study }\end{array}$ & $\begin{array}{c}\text { Study Sample } \\
\text { (sample size, data source, age } \\
\text { group included and study design) }\end{array}$ & Ethnic groups included & Outcome Examined & Comments \\
\hline $\begin{array}{l}\text { 46. Pawliuk et al., } 1996 \\
\text { (Montreal, Canada) }^{72}\end{array}$ & $\begin{array}{l}\mathrm{N}=34 \text { multiethnic families (one parent } \\
\text { included) with a total of } 48 \text { children (of which } 8 \\
\text { born in Asia and } 3 \text { in India. No other mention } \\
\text { of the ethnic breakdown of the children). } \\
\mathrm{A}=\text { age range of parents not given but children } \\
\text { ranged in age from } 6.5 \text { to } 17 \text { years old } \\
\mathrm{S}=\text { convenience sample of the parents and } \\
\text { their children seen in a Pediatric Clinic in } \\
\text { Montreal, Canada } \\
\mathrm{D}=\text { Cross-sectional } \\
\text { DA = ANOVA and MANOVA } \\
\mathrm{T}=\text { Analytic }\end{array}$ & $\begin{array}{l}\text { Ethnic breakdown of the } \\
\text { parents given but not for the } \\
\text { children. } \\
\text { Asian [26]; } \\
\text { European [5]; } \\
\text { Indian/S. American/Middle } \\
\text { Eastern [3] }\end{array}$ & $\begin{array}{l}\text { DV: Revised CBCL; Depression } \\
\text { Self-rating Scale; the What I } \\
\text { Think and Feel Scale; the } \\
\text { Children's Psycho-somatic } \\
\text { Symptom Checklist; and the } \\
\text { Hare Self-Esteem Scale. }\end{array}$ & $\begin{array}{l}\text { 1. No explicit definition given for ethnicity } \\
\text { 2. There were } 34 \text { parents and } 48 \text { children so } \\
\text { unclear of the ethnicity breakdown of the } \\
\text { children. } \\
\text { 3. Since ethnicity for parents given but not for } \\
\text { children, it appears that ethnicity based on } \\
\text { region/place of parent's birth. }\end{array}$ \\
\hline $\begin{array}{l}\text { 47. Zapf et al., } 1996 \\
\text { (Vancouver, British }^{\text {Columbia, Canada) }}{ }^{73}\end{array}$ & $\begin{array}{l}\mathrm{N}=790 \\
\mathrm{~A}=\text { not specified } \\
\mathrm{S}=\text { Adult males randomly selected from } \\
\text { Vancouver Pretrial Service Centre between } \\
\text { August } 1,1989 \text { and July } 31,1990 \\
D=\text { Cross-sectional } \\
D A=\text { Chi-square and Pearson Correlation } \\
\text { Analyses } \\
T=\text { Descriptive }\end{array}$ & $\begin{array}{l}\text { Although the term "ethnicity" } \\
\text { used, there was no } \\
\text { breakdown of the ethnic } \\
\text { group. }\end{array}$ & $\begin{array}{l}\text { DV: Mental disorder per the } \\
\text { BPRS and the Diagnostic } \\
\text { Profile }\end{array}$ & $\begin{array}{l}\text { 1. Ethnicity stated as a covariate. } \\
\text { 2. No definition given for ethnicity. } \\
\text { 3. No indication of how ethnicity } \\
\text { conceptualized or operationalized. }\end{array}$ \\
\hline $\begin{array}{l}\text { 48. Devins et al., } 2000 \\
\text { (Canada \& US) }^{74}\end{array}$ & $\begin{array}{l}N=405 \\
A=\text { not specified } \\
S=\text { The Arthritis, Rheumatism and Aging } \\
\text { Medical Information System Lupus Project } \\
D=\text { Longitudinal } \\
D A=\text { Principal component and path analyses } \\
T=\text { Analytic }\end{array}$ & $\begin{array}{l}\text { White [335]; } \\
\text { Black [40]; } \\
\text { Asian [30] } \\
\text { (all female) }\end{array}$ & $\begin{array}{l}\text { DV: Psychosocial well-being } \\
\text { (ABS); learned helplessness } \\
\text { (RAI); emotional distress } \\
\text { (CES-D); musculo-skeletal pain } \\
\text { (HAQ); overall psycho-social } \\
\text { well-being }\end{array}$ & $\begin{array}{l}\text { 1. The Black and Asian groups comprised of } \\
\text { mostly (i.e. } 97 \% \text { \& } 83 \% \text { ) individuals from } \\
\text { the US, whereas almost equal proportion of } \\
\text { whites from the US and Canada). } \\
\text { 2. Racial classification rather than ethnicity. }\end{array}$ \\
\hline $\begin{array}{l}\text { 49. Hodelet, } 2001 \\
\text { (British Columbia, } \\
\text { Canada) }^{75}\end{array}$ & $\begin{array}{l}N=175 \\
A=19 \text { to } 75 \\
S=\text { Secure Forensic Psychiatry Hospital, all case } \\
\text { records for patients in hospital between } \\
\text { December } 1,1998 \text { and February } 28,1999 \\
D=\text { Cross-sectional } \\
D A=\text { Chi-square and ANOVA analyses } \\
T=\text { Descriptive }\end{array}$ & $\begin{array}{l}\text { White [153]; } \\
\text { Native American [26]; } \\
\text { Oriental/East Asian [11]; } \\
\text { South Asian [5]; } \\
\text { Black [1] }\end{array}$ & $\begin{array}{l}\text { DV: Type of offence; type of } \\
\text { psychiatric diagnosis; } \\
\text { psychosis; psychotic drive }\end{array}$ & $\begin{array}{l}\text { 1. Explicit definition of ethnicity not given. } \\
\text { 2. "Ethnic origin" indicated but unclear how } \\
\text { this was ascertained in the individuals' } \\
\text { medical records. }\end{array}$ \\
\hline
\end{tabular}

